\title{
Differential Presynaptic Localization of Metabotropic Glutamate Receptor Subtypes in the Rat Hippocampus
}

\author{
Ryuichi Shigemoto, ${ }^{1}$ Ayae Kinoshita, ${ }^{1}$ Eiki Wada, ${ }^{1}$ Sakashi Nomura, ${ }^{3}$ Hitoshi Ohishi, ${ }^{1}$ Masahiko Takada, ${ }^{1}$ \\ Peter J. Flor, ${ }^{4}$ Akio Neki, ${ }^{2}$ Takaaki Abe, ${ }^{2}$ Shigetada Nakanishi, ${ }^{2}$ and Noboru Mizuno ${ }^{1}$ \\ Departments of ${ }^{1}$ Morphological Brain Science and ${ }^{2}$ Biological Sciences, Faculty of Medicine, and ${ }^{3}$ College of Medical \\ Technology, Kyoto University, Kyoto 606, Japan, and ${ }^{4}$ Novartis Pharma Inc., Nervous System Research, \\ $\mathrm{CH}-4002$ Basel, Switzerland
}

\begin{abstract}
Neurotransmission in the hippocampus is modulated variously through presynaptic metabotropic glutamate receptors (mGluRs). To establish the precise localization of presynaptic mGluRs in the rat hippocampus, we used subtype-specific antibodies for eight mGluRs (mGluR1-mGluR8) for immunohistochemistry combined with lesioning of the three major hippocampal pathways: the perforant path, mossy fiber, and Schaffer collateral. Immunoreactivity for group II (mGluR2) and group III (mGluR4a, mGluR7a, mGluR7b, and mGluR8) mGluRs was predominantly localized to presynaptic elements, whereas that for group I mGluRs (mGluR1 and mGluR5) was localized to postsynaptic elements. The medial perforant path was strongly immunoreactive for mGluR2 and mGluR7a throughout the hippocampus, and the lateral perforant path was prominently immunoreactive for mGluR8 in the dentate gyrus and CA3 area. The mossy fiber was labeled for mGluR2, mGluR7a, and mGluR7b, whereas the Schaffer collateral was labeled only for
\end{abstract}

mGluR7a. Electron microscopy further revealed the spatial segregation of group II and group III mGluRs within presynaptic elements. Immunolabeling for the group III receptors was predominantly observed in presynaptic active zones of asymmetrical and symmetrical synapses, whereas that for the group II receptor (mGluR2) was found in preterminal rather than terminal portions of axons. Target cell-specific segregation of receptors, first reported for mGluR7a (Shigemoto et al., 1996), was also apparent for the other group III mGluRs, suggesting that transmitter release is differentially regulated by 2-amino-4phosphonobutyrate-sensitive mGluRs in individual synapses on single axons according to the identity of postsynaptic neurons.

Key words: metabotropic glutamate receptor; hippocampus; perforant path; mossy fiber; Schaffer collateral; axon terminal; preterminal; immunohistochemistry; lesion
Metabotropic glutamate receptors (mGluRs) have various modulatory functions on neuronal excitability, transmitter release, and synaptic plasticity in the CNS (Pin and Duvoisin, 1995). These functions have been studied most extensively in the hippocampus because of its roles in learning and memory and of its architecture, which is compartmentalized well with the three major excitatory pathways: the perforant path, mossy fiber, and Schaffer collateral. The mGluRs consist of at least eight subtypes that are classified into three groups (Nakanishi and Masu, 1994; Pin and Duvoisin, 1995). Group I mGluRs (mGluR1/mGluR5) are selectively activated by 3,5-dihydroxyphenylglycine (DHPG) (Schoepp et al., 1994) and coupled to inositol phospholipid hydrolysis. On the other hand, group II mGluRs (mGluR2/ mGluR3) and group III mGluRs (mGluR4/mGluR6/mGluR7/ mGluR8), which are linked to inhibition of the cAMP cascade in receptor-transfected cell lines, are selectively activated by 2-(2,3-

Received March 28, 1997; revised July 14, 1997; accepted July 16, 1997.

This work was supported by research grants from the Inamori Foundation and the Ministry of Education, Science, Sports and Culture of Japan. We thank Peter Somogyi for helpful discussion, David Roberts for technical assistance, and Akira Uesugi for photographic assistance. We are grateful to Atsu Aiba, David Hampson, John Roder, and Herman van der Putten for providing us with mGluR1-, mGluR4-, mGluR5-, and mGluR7-deficient mice, respectively, and to Corrado Corti and Francesco Ferraguti for sharing rat mGluR8 cDNA and unpublished results.

Correspondence should be addressed to Dr. Ryuichi Shigemoto, Department of Morphological Brain Science, Faculty of Medicine, Kyoto University, Yoshida, Sakyo-ku, Kyoto 606, Japan.

Copyright (C) 1997 Society for Neuroscience $\quad 0270-6474 / 97 / 177503-20 \$ 05.00 / 0$ dicarboxycyclopropyl)glycine (DCG-IV) (Hayashi et al., 1993) and 2-amino-4-phosphonobutyrate (L-AP4), respectively.

Excitability of hippocampal neurons is modulated directly through group I mGluRs (Davies et al., 1995; Gereau and Conn, 1995b) coupled to various calcium, potassium, and nonselective cationic channels (Swartz and Bean, 1992; Crépel et al., 1994; Guérineau et al., 1994, 1995). This is consistent with the postsynaptic location of mGluR1/mGluR5 immunoreactivity in hippocampal neurons (Luján et al., 1996). On the other hand, presynaptic mGluRs are thought to suppress transmitter release in various regions (Pin and Duvoisin, 1995) by inhibiting voltagedependent calcium channels (Takahashi et al., 1996) and/or interfering directly with the release machinery (Scanziani et al., 1995). In the hippocampus, group I and group III mGluRs mediate the inhibition of excitatory transmission in the Schaffer collateral-CA1 cell synapses (Gereau and Conn, 1995a), whereas the group II and group III mGluRs are involved in the presynaptic inhibition in the perforant path-granule cell synapses (Bushell et al., 1996a; Macek et al., 1996). Furthermore, recent studies with mGluR-deficient mutant mice have indicated that not only postsynaptic but also presynaptic mGluRs have roles in hippocampal synaptic plasticity (Bushell et al., 1996b; Yokoi et al., 1996).

The mRNAs for all mGluRs except mGluR6 are expressed in the hippocampus and entorhinal cortex (Shigemoto et al., 1992; Ohishi et al., 1993a,b, 1995a; Fotuhi et al., 1994; Saugstad et al., 1994). Immunolabeling for mGluR $2 / 3$ and mGluR 7 a was found in 
presynaptic elements in the hippocampus using subtype-specific antibodies (Shigemoto et al., 1995, 1996; Bradley et al., 1996; Petralia et al., 1996; Yokoi et al., 1996). We also developed antibodies specific to mGluR4a and mGluR8 and found these immunoreactivities in axon terminals in other brain regions (Kinoshita et al., 1996a,b). In the present study, we systematically used 10 subtype-specific mGluR antibodies, including a newly developed mGluR7b-specific antibody, to examine the precise localization of presynaptic mGluRs in the rat hippocampus by light and electron microscopy, in combination with lesion experiments to establish the origins of presynaptic mGluR-bearing pathways.

\section{MATERIALS AND METHODS}

Preparation of affinity-purified antibodies against $m G l u R s$. Antibodies for mGluR1 $\alpha$, mGluR1, mGluR2/3, mGluR2, mGluR5, and mGluR7a were raised against bacterial fusion proteins containing mGluR sequences (amino acid residues 859-1199 of mGluR1 $\alpha, 104-154$ of mGluR1, 87134 and 813-872 of mGluR2, 863-1171 of mGluR5a, and 874-915 of mGluR7a) as described previously (Shigemoto et al., 1993, 1994, 1996; Ohishi et al., 1994, 1995b; Neki et al., 1996). One mGluR1 antibody (G18) raised against extracellular amino acid residues 104-154 is specific to all spliced forms of mGluR1 (pan mGluR1 antibody) (Shigemoto et al., 1994), whereas another (A52) raised against intracellular C-terminal residues $859-1199$ of $m$ GluR $1 \alpha$ is specific to mGluR1 $\alpha$ (see Results). The antibody (H12) raised against intracellular $\mathrm{C}$-terminal residues 813-872 of mGluR2 is reactive to both mGluR2 and mGluR3 (mGluR2/3 antibody) (Ohishi et al., 1994), whereas another mGluR2 monoclonal antibody (mG2Na-5) raised against putative extracellular amino acid residues $87-134$ is mGluR2-specific (Neki et al., 1996). The mGluR5 antibody is reactive to the C-terminal domain common for mGluR5a and mGluR5b (Minakami et al., 1993). Antibodies for mGluR4a (K44), mGluR6, and mGluR8 (K88) were raised against synthetic peptides corresponding to $\mathrm{C}$-terminal sequences (amino acid residues $890-912$ of mGluR4a, 853-871 of mGluR6, and 886-908 of mGluR8) as described previously (Nomura et al., 1994; Kinoshita et al., 1996a,b). The antibodies for mGluR1, mGluR1 $\alpha$, mGluR2/3, mGluR5, mGluR6, and mGluR7a are polyclonal antibodies raised in rabbits, whereas those for mGluR4a and mGluR8 are polyclonal antibodies raised in guinea pigs. An antibody for mGluR7b (K74) was newly raised against a synthetic peptide corresponding to the human mGluR7bspecific C-terminal sequence (NCIPPVRKSVQKSVTWYTIPPTV) (Flor et al., 1997) as described previously (Kinoshita et al., 1996a). The amino acid sequence used for the antibody production is identical between the human and rat mGluR7b (F. Ferraguti, personal communication). After conjugation with maleimide-activated bovine serum albumin (Pierce, Rockford, IL), the peptide was injected subcutaneously in rabbits and guinea pigs $(0.5-1.0 \mathrm{mg}$ of peptide/animal). The immunized animals were boosted every 4 weeks and bled 1-2 weeks after each boost. The collected antisera were purified by sodium sulfate fractionation, followed by affinity chromatography on a SulfoLink (Pierce) coupled to the C-terminus peptide. The purified mGluR7b antibodies derived from rabbits and guinea pigs gave identical results.

Immunoblot analysis. Immunoblot analysis was performed as described previously (Shigemoto et al., 1994). The crude membrane preparations from rat hippocampus and mGluR4-, mGluR6-, mGluR7a- and mGluR7b-expressing Chinese Hamster Ovary (CHO) cells (Tanabe et al., 1992; Nakajima et al., 1993; Okamoto et al., 1994; Flor et al., 1997) were separated by $7 \%$ SDS-PAGE and transferred to polyvinylidene difluoride (PVDF) membranes. The membranes were blocked with Block-Ace (Dainippon Pharmaceutical) and then reacted with the affinity-purified mGluR antibodies $(0.2-1.0 \mu \mathrm{g} / \mathrm{ml})$ in the absence or presence of respective fusion proteins. Alkaline phosphatase-labeled secondary antibodies (Chemicon, Temecula, CA) were used to visualize the reacted bands.

Surgery. At least three adult male Wistar rats (250-300 gm) were used for each series of experiments. All surgical manipulations were performed using a David Kopf stereotaxic apparatus under anesthesia with sodium pentobarbital $(50 \mathrm{mg} / \mathrm{kg}$, i.p.). A lesion generator (Radionics Inc.) was used at the setting of $60^{\circ} \mathrm{C}$ for 2 min to make lesions in the entorhinal cortex and subiculum. For destruction of dentate granule cells, colchicine (Sigma, St. Louis, MO) (3 $\mu \mathrm{g}$ in $0.9 \mu \mathrm{l}$ of $25 \mathrm{~mm}$ PBS, $\mathrm{pH} 7.3)$ was injected through a
$1 \mu \mathrm{l}$ Hamilton microsyringe into the dorsal and ventral hilus of the left hippocampus as described previously (McGinty et al., 1983). For destruction of CA3 pyramidal cells, kainic acid (Sigma) was injected into the CA areas of the left hippocampus or bilateral ventricles at the dose of $0.2 \mu \mathrm{g}$ in $0.2 \mu \mathrm{l}$ PBS or $0.6 \mu \mathrm{g}$ in $1.2 \mu \mathrm{l}$ PBS, respectively. In some experiments, PBS alone was injected into the corresponding sites of the right hippocampus or bilateral ventricles to serve as controls. Seven days after the lesioning or injections of colchicine or kainic acid, the rats were killed and processed for immunohistochemistry.

Immunohistochemistry. Immunohistochemical staining was performed by the $\mathrm{ABC}$ and double-immunofluorescence methods as described previously (Shigemoto et al., 1993, 1996). For light microscopy, adult male Wistar rats as well as wild-type and mGluR-deficient mice were deeply anesthetized and perfused transcardially with $3.5 \%$ paraformaldehyde, $1 \%$ picric acid, and $0.05 \%$ glutaraldehyde in $0.1 \mathrm{M}$ phosphate buffer $(\mathrm{PB})$, $\mathrm{pH}$ 7.3. For immunolabeling with the mGluR2 antibody (mG2Na-5), brains were further fixed for $3 \mathrm{~d}$ at $4^{\circ} \mathrm{C}$ in a mixture containing $2 \%$ formaldehyde and $1 \%$ picric acid in $0.1 \mathrm{M} \mathrm{PB}, \mathrm{pH} 7.3$ (Neki et al., 1996). Tissue blocks containing the hippocampus were cryoprotected in $20 \%$ sucrose in $0.1 \mathrm{M} \mathrm{PB}$ overnight at $4^{\circ} \mathrm{C}$ and cut on a freezing microtome into $40-\mu \mathrm{m}$-thick sections. The sections were incubated with $0.5-1.0 \mu \mathrm{g} / \mathrm{ml}$ antibodies for mGluRs in PBS containing $2 \%$ normal goat serum and $0.1 \%$ Triton $\mathrm{X}-100$ overnight at $15^{\circ} \mathrm{C}$. After washes in PBS, the sections were incubated with biotinylated goat anti-rabbit, goat anti-guinea pig, or goat anti-mouse IgG (Vector Laboratories, Burlingame, CA). The sections were then washed again, reacted with the ABC kit (Vector), and finally incubated with $0.05 \%$ diaminobenzidine and $0.0006 \%$ hydrogen peroxide. For double-immunofluorescence histochemistry, $20-\mu \mathrm{m}$-thick sections were reacted with antibodies to mGluRs $(0.5-1.0 \mu \mathrm{g} / \mathrm{ml})$ and then with fluorescein isothiocyanate-conjugated anti-[rabbit $\mathrm{IgG}]$ antibody and biotinylated anti-[guinea pig IgG] antibody combined with Texas Red-conjugated avidin. When either of the primary antibodies was omitted, no fluorescence signal for the omitted primary antibody was observed (not shown). For electron microscopy, rats were perfused with $4 \%$ paraformaldehyde, $0.2-1.0 \%$ picric acid, and $0.05-0.1 \%$ glutaraldehyde in $0.1 \mathrm{M} \mathrm{PB}, \mathrm{pH} 7.3$. Tissue blocks were then processed by two separate methods. In the first method, $50-\mu \mathrm{m}$-thick sections were cut on a vibratome and processed as described above for light microscopy, except that $0.2 \%$ photoflo (Kodak) was used instead of Triton X-100. In the second method, tissue blocks were freeze-thawed in liquid nitrogen and PBS at room temperature, and 50- $\mu \mathrm{m}$-thick sections were cut on a vibratome. The sections from freeze-thawed tissues were incubated with mGluR antibodies in PBS containing 2\% normal goat serum without Triton X-100 or photoflo. After washes in PBS, sections were incubated with biotinylated or $1.4 \mathrm{~nm}$ gold-labeled (Nanoprobes, Stony Brook, NY) secondary antibodies and then reacted with the ABC or HQ Silver kit (Nanoprobes), respectively. After osmification, the immunostained sections were block-stained with uranyl acetate, dehydrated, and flatembedded in Epon. Ultrathin sections were then prepared and examined with a Hitachi H-7100 electron microscope. Some sections with immunogold labeling were counterstained with lead citrate.

\section{RESULTS}

\section{Immunoblot analysis of mGluRs in the hippocampus}

Specificity of the antibodies used in the present study was verified with immunoblot analysis of a crude membrane fraction prepared from the rat hippocampus (Fig. 1A). Pan mGluR1 antibody (G18) gave rise to two immunoreactive products with estimated molecular masses of 145 and $97 \mathrm{kDa}$. The former corresponds to mGluR1 $\alpha$ (Masu et al., 1991) and the latter to mGluR1 $\beta$ (Tanabe et al., 1992), mGluR1c (Pin et al., 1992), and mGluR1d (Laurie et al., 1996). Only the former was detected with another mGluR1 antibody (A52) raised against $\mathrm{C}$-terminal residues of $\mathrm{mGluR} 1 \alpha$, indicating that $\mathrm{A} 52$ is specific to $\mathrm{mGluR} 1 \alpha$. Two immunoreactive products of $98 \mathrm{kDa}$ and $\sim 200 \mathrm{kDa}$ were observed with the mGluR2/3 (H12) and mGluR2 (mG2Na-5) antibodies. The former product corresponds to $\mathrm{mGluR} 2$, and the latter probably represents dimeric forms of mGluR2/3 proteins (Hayashi et al., 1993; Ohishi et al., 1994). Presumed dimeric forms were found for most mGluRs (Baude et al., 1993; Shigemoto et al., 1993; Nomura et al., 1994; Petralia et al., 1996; Romano et al., 1996) (also see the 


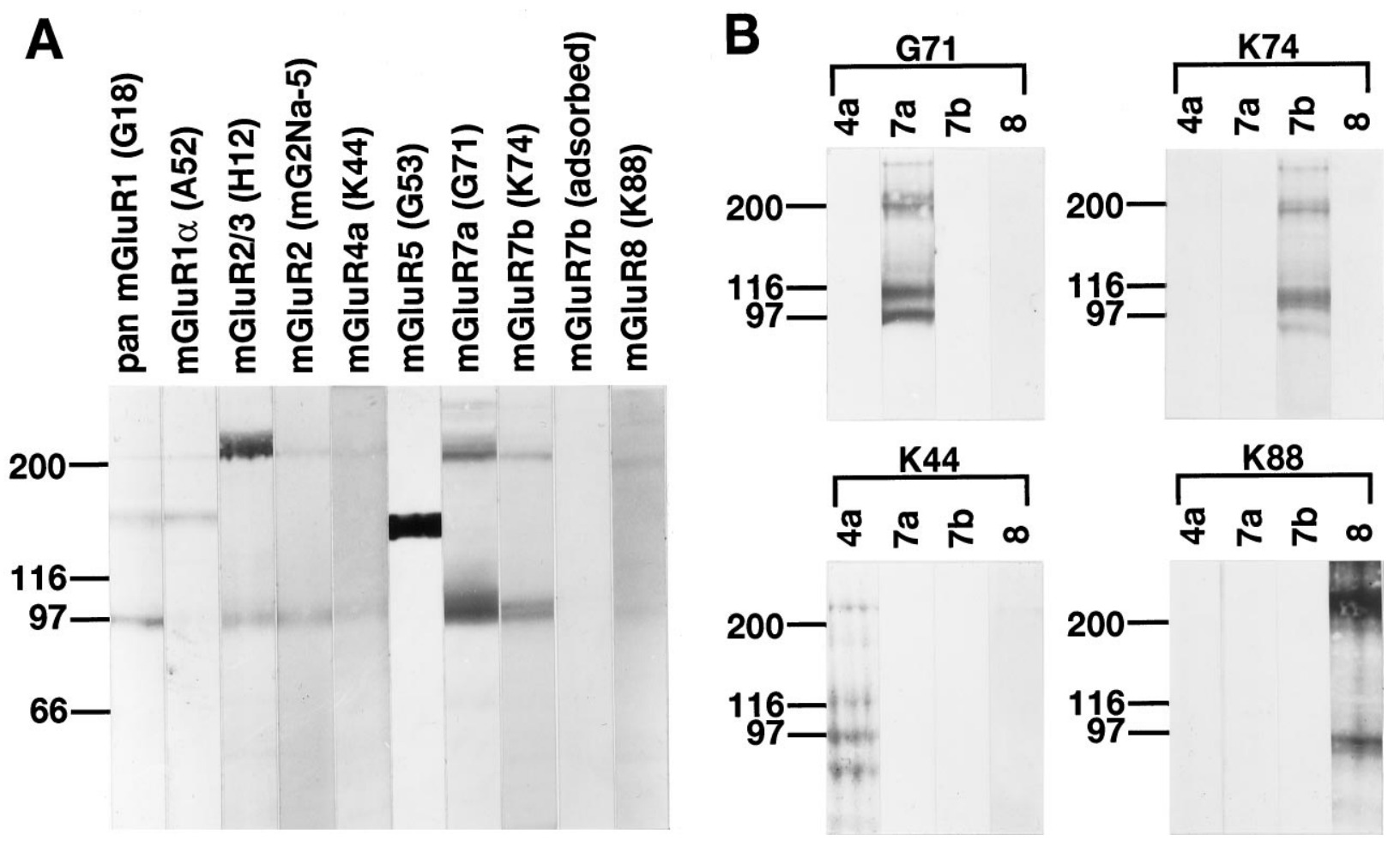

Figure 1. Immunoblot analysis of rat hippocampus $(A)$ and receptor-expressing cells $(B)$. Crude membrane preparations from rat hippocampus and CHO cells expressing mGluR4a (4a), mGluR7a (7a), or mGluR7b (7b), or COS cells transfected with mGluR8 cDNA (8) were subjected to 7\% SDS-PAGE and transferred onto PVDF filters. $A$, The filters with the hippocampus were reacted with antibody to pan mGluR1 (G18), mGluR1 $\alpha$ (A52), mGluR2/3 (H12), mGluR2 (mG2Na-5), mGluR4a (K44), mGluR5 (G53), mGluR7a (G71), mGluR7b (K74), or mGluR8 (K88). Immunoreactive bands for mGluR7b were completely abolished by preadsorption of the antibody with the corresponding peptide (adsorbed). $B$, The filters with the receptor-expressing cells were reacted with the mGluR7a (G71), mGluR7b (K74), mGluR4a (K44), or mGluR8 (K88) antibody. Each of the immunoreactive products was absent in nontransfected cells (not shown). Positions of molecular mass markers (Bio-Rad) in kDa are indicated on the left.

present results for mGluR4a, mGluR7a, mGluR7b, and mGluR8). The extracellular mGluR2-specific antibody (mG2Na-5) gave a similar immunoreactive product of $98 \mathrm{kDa}$ but only weakly reacted with the product of $\sim 200 \mathrm{kDa}$. This result may be attributed to low accessibility of the extracellular epitope in the dimeric form (Romano et al., 1996). In the present study, the mGluR3immunoreactive product of $106 \mathrm{kDa}$ observed in the cerebral cortex (Hayashi et al., 1993) and whole brain (Ohishi et al., 1994) was scarcely detected in the hippocampus. Immunoreactive bands of molecular masses around $100 \mathrm{kDa}$ were observed for mGluR4a, mGluR7a, and mGluR8, and that of $145 \mathrm{kDa}$ was found for mGluR5, as reported previously (Shigemoto et al., 1993, 1996; Kinoshita et al., 1996a,b). Immunoreactivity for mGluR5 and mGluR7a was strong in the hippocampus, whereas that for mGluR4a or mGluR8 was much weaker in the hippocampus than in the cerebellum (Kinoshita et al., 1996b) or in the piriform cortex (Kinoshita et al., 1996a), respectively. The newly developed mGluR7b antibody gave rise to an immunoreactive doublet with estimated molecular masses of 102 and $96 \mathrm{kDa}$. These molecular masses agree well with that of the cloned human mGluR7b (103,082 Da) (Flor et al., 1997). Two such immunoreactive bands with slightly different molecular masses were also observed for mGluR6 in the retina (Nomura et al., 1994) and may result from different post-translational modification, such as glycosylation and proteolytic cleavage. All immunoreactivities described above disappeared after preadsorption of the antibodies with the corresponding fusion proteins or synthetic peptides (Fig. $1 A$; shown only for mGluR7b). The homology between the amino acid se- quences used for the production of the mGluR antibodies was highest among group III mGluRs (52\% for mGluR4a and mGluR8, 35\% for mGluR4a and mGluR7a, and 30\% for mGluR7a and mGluR8). To exclude the possibility of cross-reactivity to other group III mGluRs, the mGluR4a, mGluR7a, and mGluR8 antibodies were incubated with excess amounts (10 times more antigens than those used for the homologous preadsorption controls) of heterologous antigens for other group III mGluRs. The preincubated antibodies gave results (data not shown) identical to those shown in Figure $1 A$. The mGluR7a antibody was purified with a column coupled to a glutathione $S$-transferase-fusion protein containing 20 amino acid residues from the C-terminal (Ohishi et al., 1995 b) that have four amino acid residues (896-899) in common with mGluR7b (Flor et al., 1997). To exclude possible crossreactivity of the mGluR7a and mGluR7b antibodies to each other and to other group III mGluRs, membrane fractions prepared from cDNA-transfected cell lines expressing mGluR4a, mGluR7a, mGluR7b, and mGluR8 were subjected to immunoblot analysis. Both the mGluR7a and mGluR7b antibodies as well as mGluR4a and mGluR8 antibodies reacted specifically with the corresponding cell lines (Fig. 1B). These results indicate that the mGluR antibodies react specifically with their respective mGluRs.

\section{Immunohistochemistry of mGluRs in normal hippocampus}

All mGluR antibodies revealed specific and distinct patterns of immunoreactivity in the normal rat hippocampus (Figs. 2-6). All of these immunostaining patterns were abolished by preadsorp- 

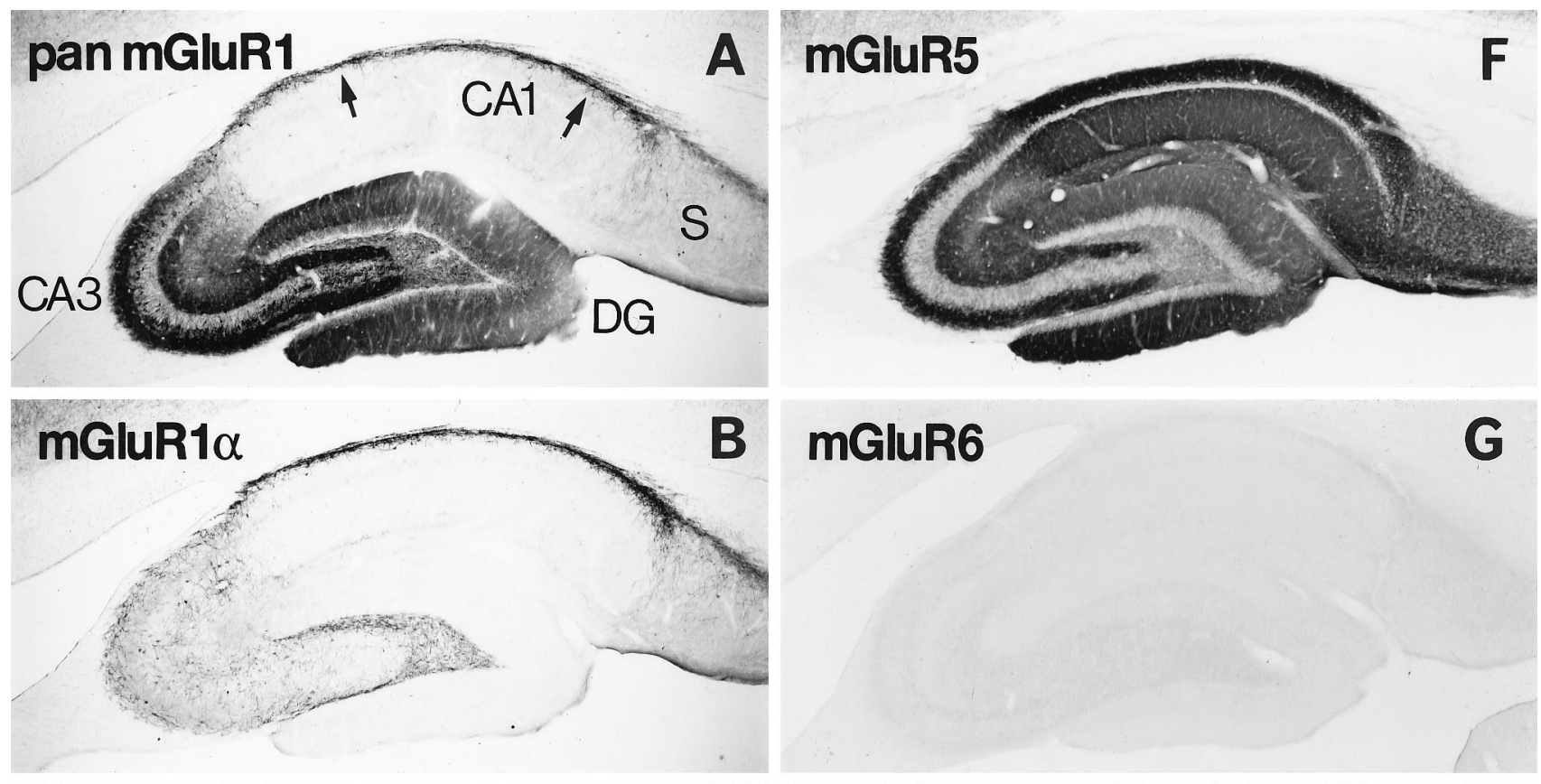

mGluR6

G
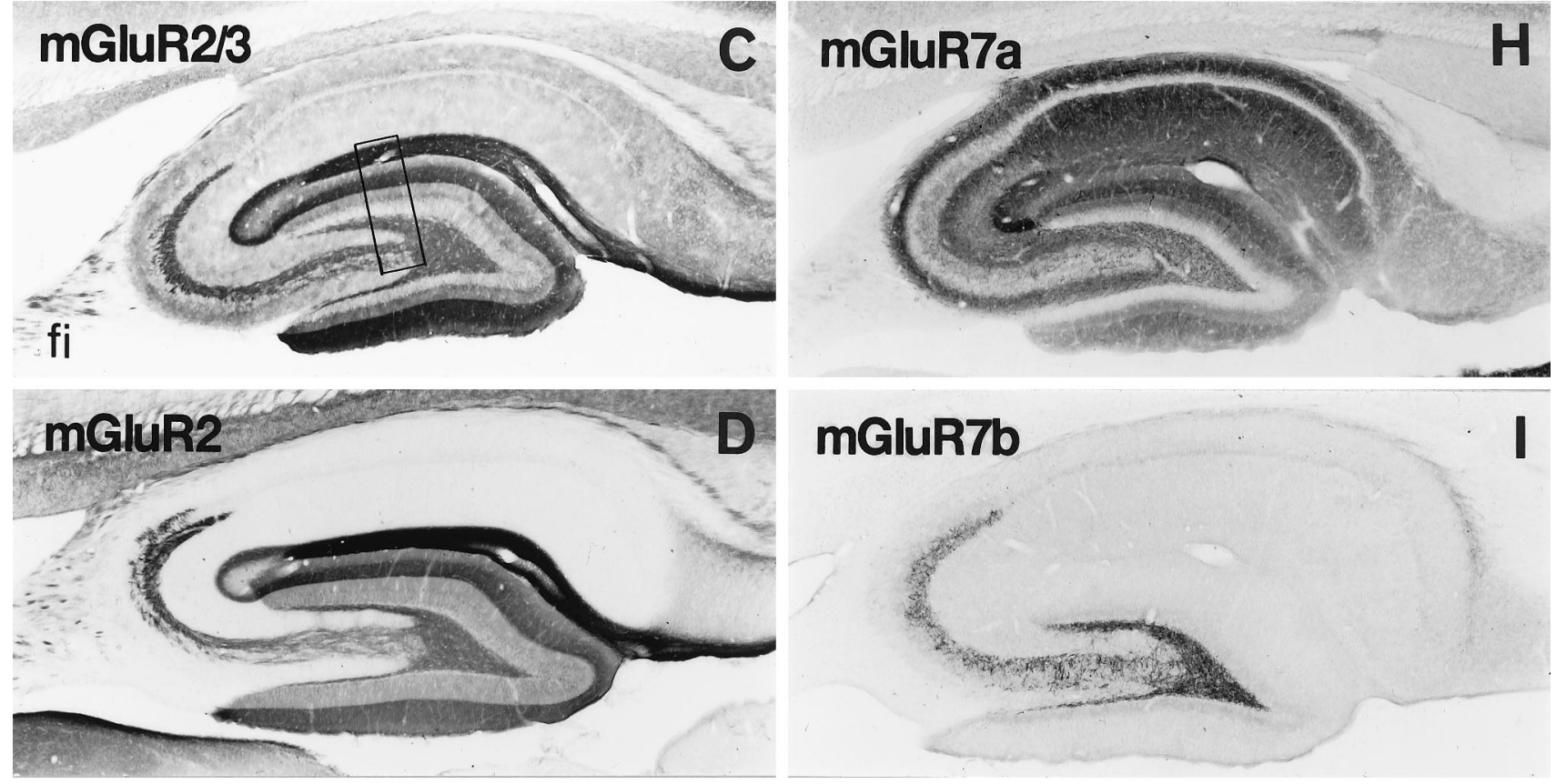

\section{mGluR7b}
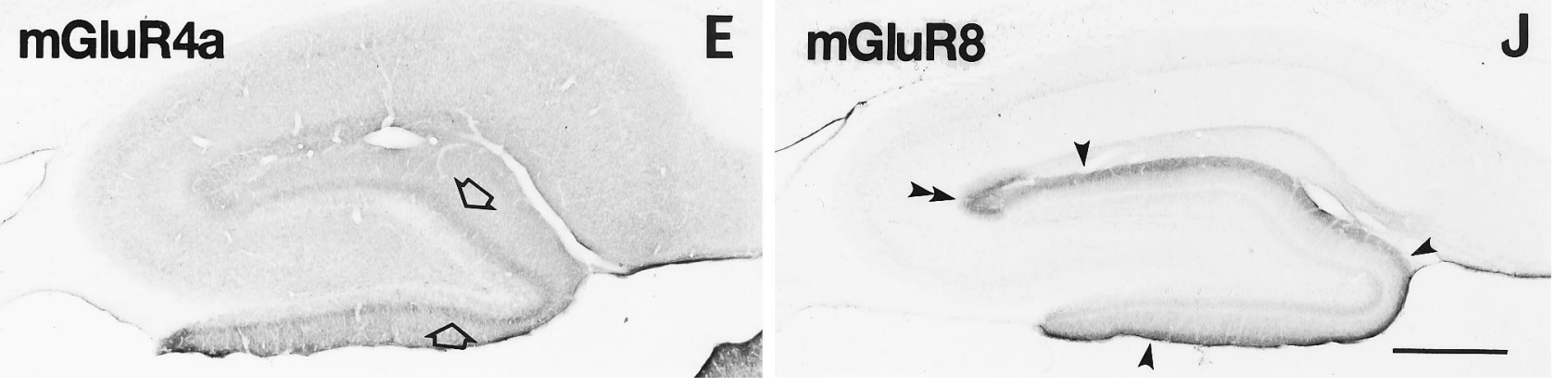

Figure 2. Distribution of immunoreactivity for eight mGluRs in rat hippocampus. Parasagittal sections through the hippocampus were reacted with antibody to pan mGluR1 $(A)$, mGluR1 $\alpha(B)$, mGluR2/3 $(C)$, mGluR2 $(D)$, mGluR4a $(E)$, mGluR5 $(F)$, mGluR6 $(G)$, mGluR7a $(H)$, mGluR7b $(I)$, or mGluR8 $(J)$. Immunoreactivity for mGluR5 $(F)$ and mGluR7a $(H)$ is distributed in all dendritic layers throughout the hippocampus, whereas immunoreactivity for the other mGluRs is restricted to distinct regions. Immunoreactivity for mGluR1 $(A)$ is strong in dendritic fields of the dentate gyrus $(D G)$ and CA3, as well as in the CA1 stratum oriens/alveus border (arrows). Immunoreactivity for mGluR1 $\alpha(B)$ is $($ Figure legend continues ) 


\section{pan mGluR1}

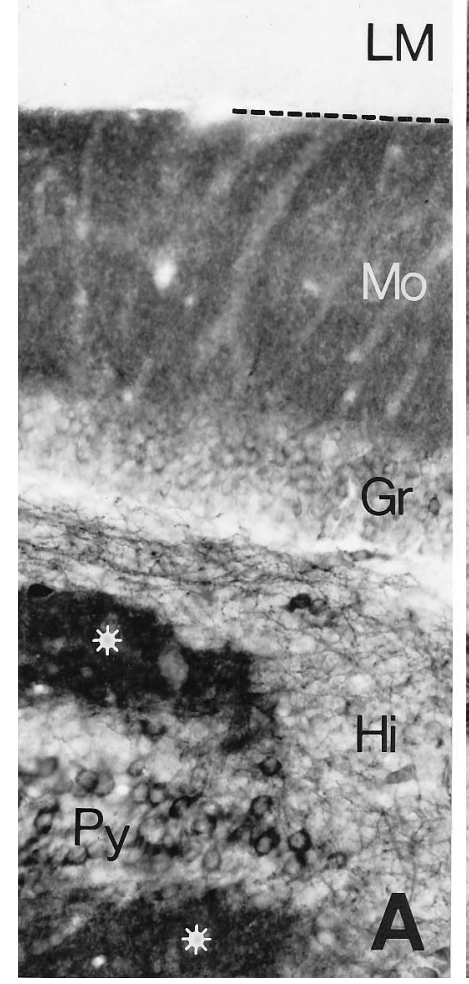

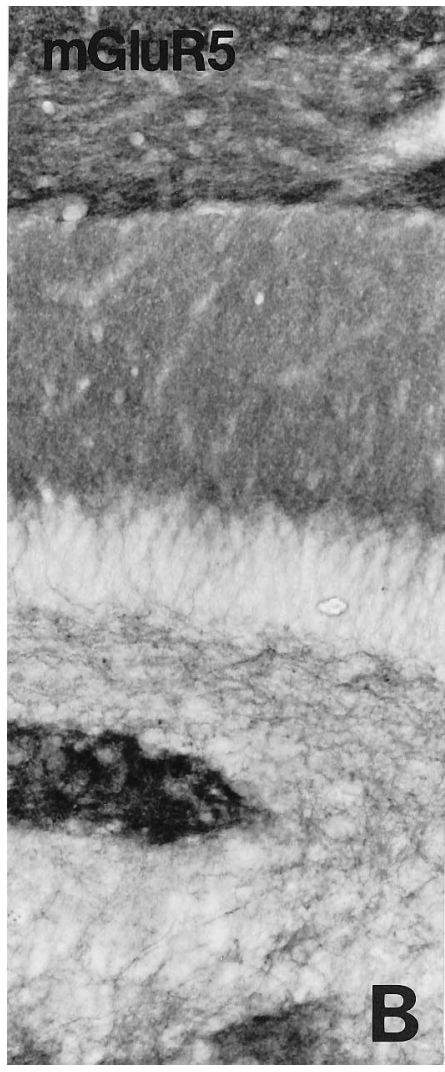

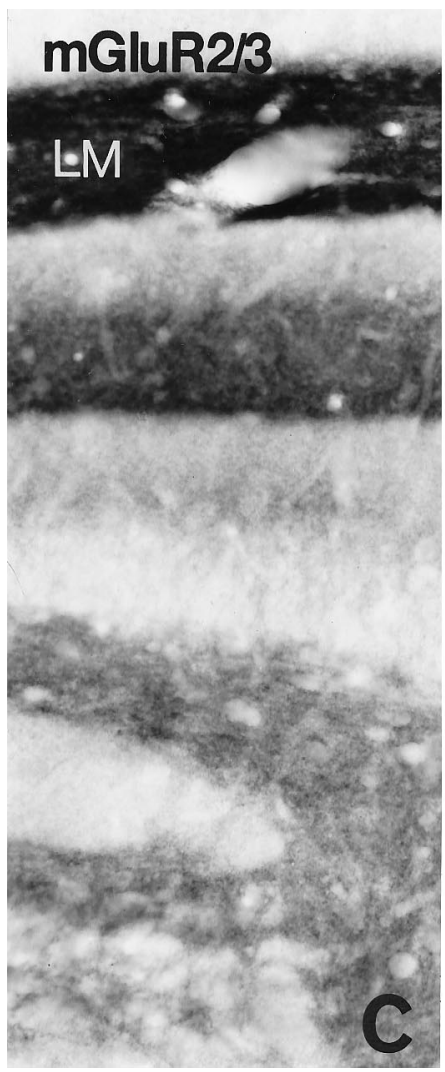

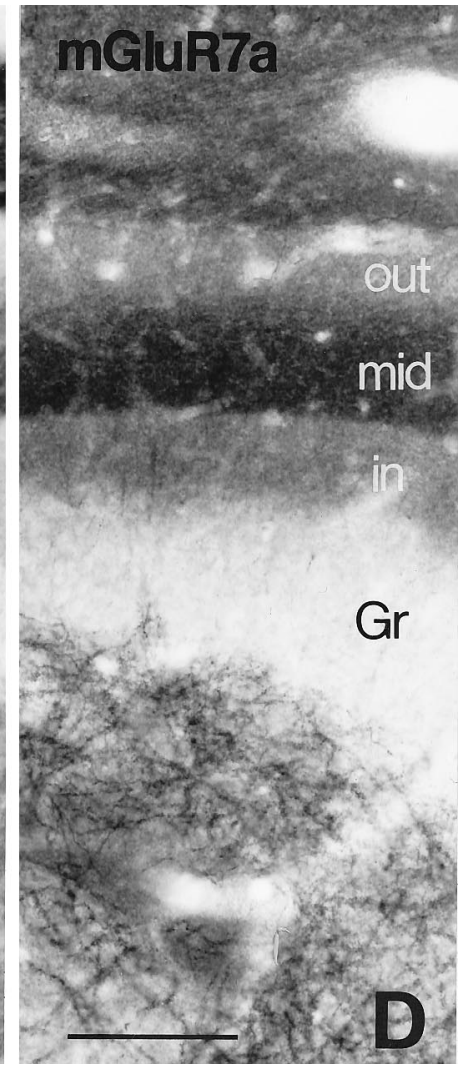

Figure 3. Distribution of immunoreactivity for mGluR1 $(A)$, mGluR5 $(B)$, mGluR2/3 $(C)$, and mGluR7a $(D)$ in the hippocampal area corresponding to the rectangle in Figure $2 C$. Immunoreactivity for mGluR1 and mGluR5 is relatively uniform throughout the dentate molecular layer $(M o)$, whereas that for mGluR2/3 and mGluR7a is prominent in the middle one-third of the layer $(\mathrm{mid})$, which is the terminal zone of the medial perforant path. In the hilus $(\mathrm{Hi})$, dendritic profiles are immunopositive for mGluR1, mGluR5, and mGluR7a, whereas neuropil is immunopositive for mGluR2/3. Dendritic fields (stars) of CA3 pyramidal cells (Py) are immunopositive for mGluR1, mGluR5, and mGluR7a but immunonegative for mGluR2/3. Intense mGluR2/3 labeling is seen in CA1 stratum lacunosum moleculare $(L M)$. The broken line indicates the hippocampal fissure. Gr, Granule cell layer; in, inner one-third of the molecular layer; out, outer one-third of the molecular layer. Scale bar, $100 \mu \mathrm{m}$.

tion of the antibodies with the homologous but not the heterologous antigens (data not shown). For example, mGluR7a immunolabeling, which overlaps with immunolabeling for mGluR4a/ $7 \mathrm{~b} / 8$, was abolished after preadsorption of the antibody with the mGluR7a fusion protein and an mGluR7a-specific synthetic peptide (residues 900-915), but it was not affected by corresponding C-terminal peptides for mGluR4a/7b/8. Specificity of the immunostaining for mGluR1, mGluR1 $\alpha$, mGluR2, mGluR5, mGluR7a, and mGluR7b was further verified in the mice lacking the respective mGluR genes (Aiba et al., 1994; Bushell et al., 1996b; Yokoi et al., 1996; Lu et al., 1997). In wild-type mice, immunolabeling patterns similar to those in rat were observed for these receptors in the hippocampus, but they were totally absent in the respective mGluR-deficient mice (data not shown). Immunolabeling of mGluR4a in the hippocampus of wild-type mice had a laminar distribution different from that in the rat ( $R$. Shigemoto, unpublished result), but it was also absent in mGluR4-deficient mice (Pekhletski et al., 1996). Moreover, cross- reactivity of the antibodies for $\mathrm{mGluR7a} / 7 \mathrm{~b} / 8$ to $\mathrm{mGluR} 4$ and of those for mGluR4a/8 to mGluR7 were excluded by unaltered immunostaining patterns observed in mGluR4- and mGluR7deficient mice, respectively (data not shown).

Immunoreactivity for the group I mGluRs was observed in neuropil of the dendritic fields of the hippocampal principal cells as described previously (Luján et al., 1996), whereas immunoreactivity for the group II and group III mGluRs was observed more or less in a laminated fashion corresponding to the terminal zones of the major hippocampal pathways (Fig. 2). All hippocampal fields were immunopositive for mGluR5 and mGluR7a, whereas immunoreactivity for the other mGluRs was restricted to some areas or layers in the hippocampus. Immunoreactivity for mGluR6 was hardly detected in the hippocampus (Fig. $2 G$ ).

For the group I mGluRs, we used the antibodies reactive to all splice variants of mGluR1 (pan mGluR1) and mGluR5, as well as the mGluR $1 \alpha$-specific antibody. In CA 1 dendritic fields, only the mGluR5 antibody showed intense immunolabeling of neuropil,

strong only in the CA1 stratum oriens/alveus border (see Results). Immunoreactivity for mGluR2/3 $(C)$ and mGluR2 $(D)$ is strong in terminal zones of the perforant path and mossy fibers (see Results), whereas that for mGluR7b $(I)$ is restricted to the mossy fiber terminal zone, and that for mGluR8 $(J)$ to the lateral perforant path terminal zone, i.e., the outer third ( filled arrowheads) of the dentate molecular layer and outer layer (double arrowhead) of CA3 stratum lacunosum moleculare. Immunoreactivity for mGluR4a $(E)$ is weak but prominent in the inner third (open arrows) of the molecular layer. Labeling for mGluR6 $(G)$ is hardly detected in the hippocampus. The rectangle in $C$ indicates a corresponding region shown with a higher magnification in Figure 3. fi, Fimbria; $S$, subiculum. Scale bar, $500 \mu \mathrm{m}$. 

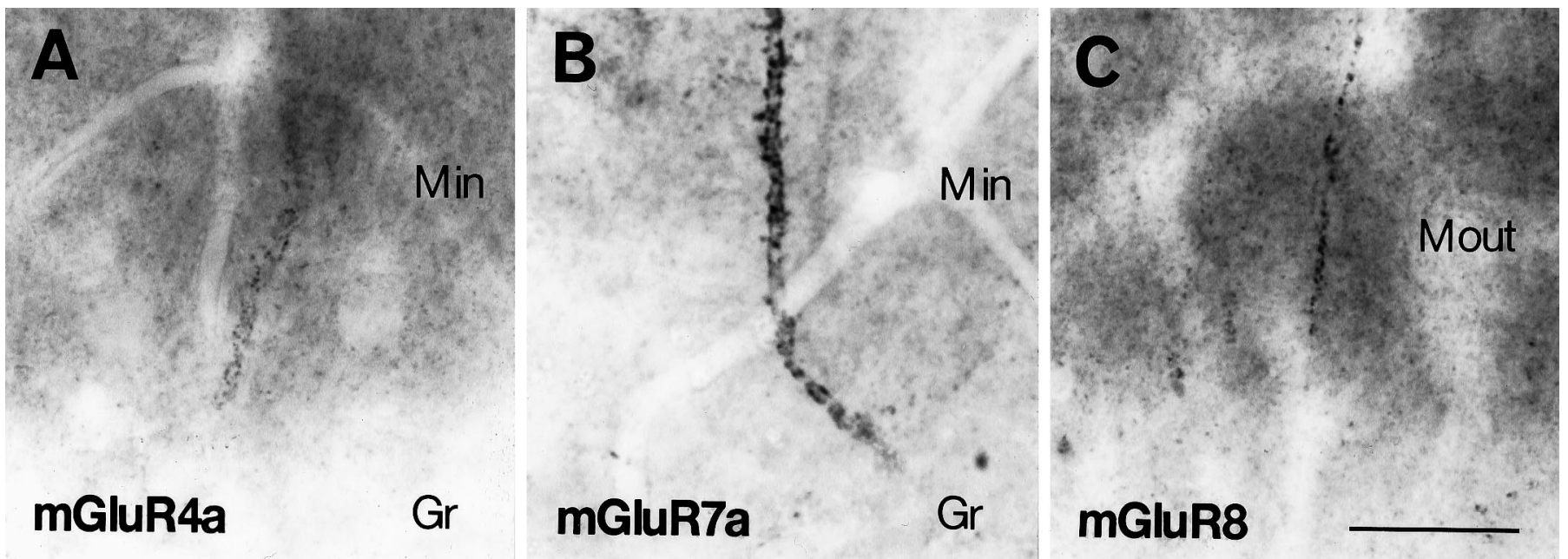

Figure 4. High-magnification micrographs showing immunoreactivity for mGluR4a $(A)$, mGluR7a $(B)$, and mGluR8 $(C)$ in the inner $(A, B)$ and outer $(C)$ third of the dentate molecular layer. Note dendritic profiles decorated with puncta immunopositive for mGluRs in the inner (Min) and outer (Mout) third of the molecular layer. Gr, Granule cell layer. Scale bar, $25 \mu \mathrm{m}$.

whereas the pan mGluR1 and mGluR5 antibodies revealed similar patterns of immunolabeling in CA3 dendritic fields and dentate molecular layer (Figs. $2 A, F, 3 A, B$ ). Cell bodies of the granule and CA3 pyramidal cells showed moderate to strong labeling for mGluR1 but only very weak labeling for mGluR5 (Fig. $3 A, B$ ). These labelings with the pan mGluR1 antibody were not detected at all with the mGluR1 $\alpha$-specific antibody (Fig. $2 B$ ), indicating that the mGluR1 immunoreactivity in CA3 pyramidal cells is ascribable to mGluR1 $\beta$, mGluR1c, and/or mGluR1d. Strong labeling for pan mGluR1 was also observed in cell bodies and dendrites of interneurons scattered in the hilus (Fig. $3 A$ ) and CA areas, being densest in the border zone between CA1 stratum oriens and the alveus (Fig. 2A). These interneurons were the only cells that were also immunopositive for mGluR1 $\alpha$ (Fig. $2 B$ ). A double-immunofluorescence labeling confirmed that all of the interneurons labeled with the pan mGluR1 antibody were also immunopositive for mGluR1 $\alpha$ throughout the hippocampus (data not shown). In the hilus, mGluR5 immunolabeling was seen in many dendritic processes (Fig. 3B). The somatodendritic profiles labeled for mGluR1 and mGluR5 were observed less frequently in CA3 stratum lucidum.

For the group II mGluRs, we used the antibody reactive to both mGluR2 and mGluR3, as well as the mGluR2-specific antibody. The immunostaining patterns with the mGluR $2 / 3$ and mGluR2 antibodies were similar (Fig. 2C,D), but some differences were seen in the strata oriens and radiatum of the CA areas, where diffuse and weak immunostaining was detected only with mGluR2/3 antibody (Fig. 2C). Such mGluR2/3 immunoreactivity was also detected in mice lacking the mGluR2 gene (Yokoi et al., 1996) and ascribed to mGluR3 immunoreactivity of glial cells (see the results of electron microscopy). The density of the mGluR2/3 and mGluR2 immunolabeling was highest in neuropil of CA1 stratum lacunosum moleculare (Figs. $2 C, D, 3 C$ ). In the $\mathrm{CA} 3$ area, labeling was stronger in the inner than in the outer layer of the stratum lacunosum moleculare, and in the dentate gyrus, it was stronger in the middle than in the outer one-third of the molecular layer (Figs. 2C,D, $3 C$ ). The strongly labeled layers correspond to the medial perforant path (Steward, 1976). A clear boundary of the strong labeling was observed between the inner and middle thirds of the molecular layer, whereas the other boundary between the outer and middle thirds of the layer was less clear (Fig. $3 C$ ). This observation again agrees well with the reported pattern of the medial perforant path projection (Steward, 1976). Immunoreactivity for mGluR2/3 and mGluR2 was also observed in neuropil of the mossy fiber terminal zone (Fig. $2 C, D$ ). Labeling of axon bundle-like profiles was apparent in CA3 stratum lucidum (see Fig. $5 A$ ) as well as in the fimbria (Fig. 2C,D). In mice lacking the mGluR2 gene, these mGluR2/3 immunolabelings were almost absent (Yokoi et al., 1996), indicating that most of the immunoreactivity in the perforant path and mossy fiber terminal zones is ascribable to mGluR2.

Among the group III mGluRs, mGluR4a, mGluR7a, mGluR7b, and mGluR8 were expressed in the hippocampus. In the CA1 area, strong neuropil labeling was observed only for mGluR7a, being strongest in the strata oriens and radiatum, followed by the stratum lacunosum moleculare (Figs. $2 \mathrm{H}, 3 \mathrm{D}$ ). Labeling in the pyramidal cell layer was very weak. In CA3 dendritic fields, very strong mGluR7a labeling was observed in CA3 stratum lacunosum moleculare, especially in the inner layer adjacent to the dentate molecular layer (Fig. $2 H$ ). The medial perforant path terminal zone in the dentate gyrus, namely the middle third of the molecular layer, was also prominently immunopositive for mGluR7a (Fig. 3D). The distribution of immunoreactivity for other group III mGluRs was much more restricted in the hippocampus. Labelings for mGluR4a and mGluR8 were weak and diffuse compared with those for mGluR2/3 and mGluR7a; however, prominent staining for mGluR4a and mGluR8 was still observed in neuropil of the inner and outer thirds of the dentate molecular layer, respectively (Figs. 2E,J, $4 A, C)$. The former corresponds to the terminal zone of the associational/commissural fibers (Swanson et al., 1978) and the latter to that of the lateral perforant path (Steward, 1976). The mGluR8 immunolabeling was stronger in the inner than in the outer blade of the dentate gyrus (Figs. $2 J, 7 H$ ); this pattern is in good accordance with that of preferential projections of the lateral perforant path (Wyss, 1981). The lateral perforant path terminal zone in CA3 stratum lacunosum moleculare (superficial portion of the layer) was also prominently immunopositive for mGluR8, making the staining pattern apparently complementary to that for mGluR2/3 (Fig. 2C). In these neuropil stainings, some 

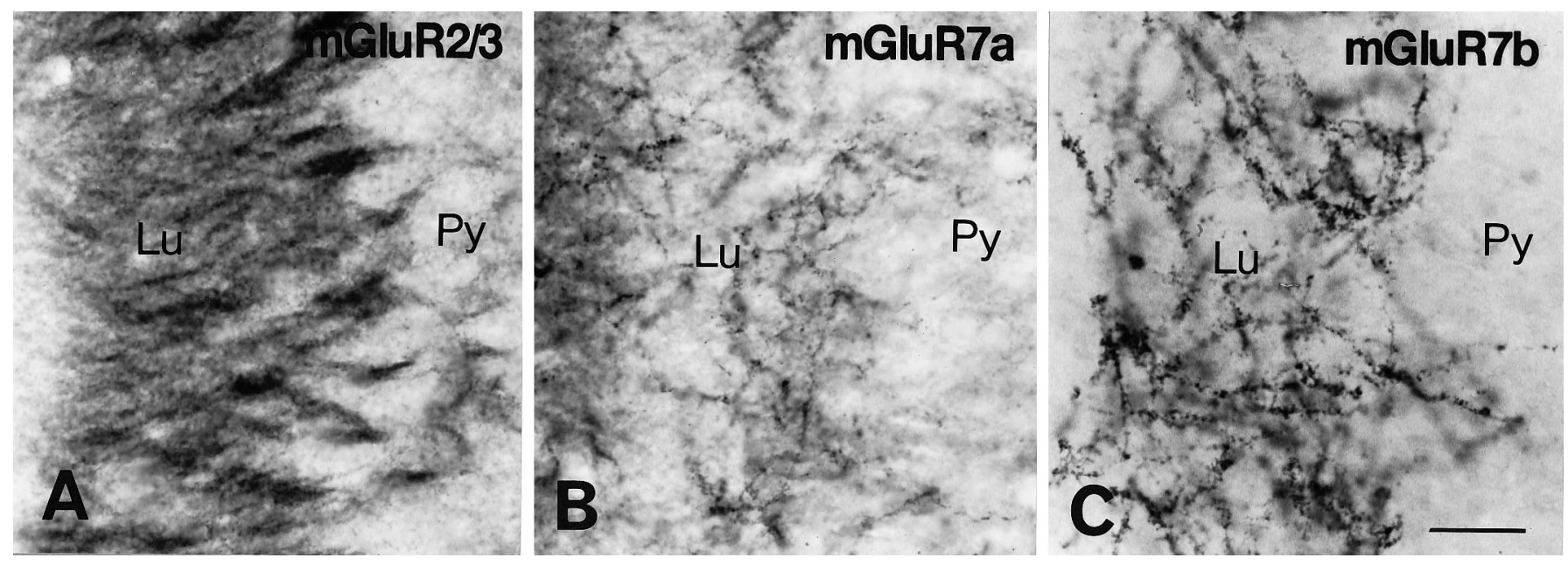

Figure 5. Immunoreactivity for mGluR2/3 $(A)$, mGluR7a $(B)$, and mGluR7b $(C)$ in CA3 stratum lucidum. Axon bundle-like profiles are immunopositive for mGluR2/3, whereas punctate decorations of dendrites are immunopositive for mGluR7a and mGluR7b in stratum lucidum $(L u)$. The pyramidal cell layer $(P y)$ is devoid of immunoreactivity. Scale bar, $25 \mu \mathrm{m}$.

dendritic profiles showed up being decorated with many axon terminals that were intensely labeled for the group III mGluRs (Fig. 4) (also see the results of electron microscopy). They were most frequently observed for mGluR7a followed by mGluR8, and only occasionally observed for mGluR4a in the molecular layer. Most of these dendrites decorated with labeled axon terminals seemed to originate from interneurons in the hilus or granule cell layer. For mGluR7a and mGluR7b, the decoration of many dendritic processes and some cell bodies of interneurons were observed in the hilus (Figs. 2H,I, 3D, 6A). In CA3 stratum lucidum, the somatodendritic decoration was observed more strongly for mGluR7b than for mGluR7a (Fig. 5B,C). The strong terminal labeling for mGluR7a on the somatodendritic profiles of interneurons was distributed most densely in the stratum oriens/alveus border zone in the CA1 area and less densely in other CA areas, as described previously (Shigemoto et al., 1996). Because these decorated interneurons were mGluR $1 \alpha$-immunopositive (Shigemoto et al., 1996), we also examined, by a double-immunofluorescence labeling, whether the decoration with mGluR7b correlates with the mGluR $1 \alpha$-immunopositive interneurons in the mossy fiber terminal zone (Fig. 6A, $A^{\prime}$ ). As in mGluR7a labeling, mGluR7b-labeled puncta were mostly found on $\mathrm{mGluR} 1 \alpha$-labeled interneurons. Colocalization of mGluR7a and mGluR7b was also examined (Fig. $\left.6 B, B^{\prime}\right)$. Virtually all mGluR7b-labeled structures were labeled for mGluR7a; however, the mGluR7a-labeled axon terminals decorating interneurons in strata oriens and radiatum of the hippocampus could be labeled only very slightly for mGluR7b.

\section{Effects of unilateral and bilateral lesions in the entorhinal cortex on immunoreactivity for mGluRs in the hippocampus}

The light microscopic findings on the distribution of mGluRs in the hippocampus support the idea that the group I and group II/III mGluRs are localized in postsynaptic and presynaptic elements, respectively. It is not always possible, however, to distinguish between the pre- and postsynaptic immunolabelings by light microscopy, especially if receptors are highly targeted to postsynaptic sites receiving particular presynaptic elements (Nusser et al., 1996) or to presynaptic sites terminating on particular postsynaptic elements (Shigemoto et al., 1996). Furthermore, in addition to the major excitatory pathways, the hippocampus con- tains many types of extrinsic and intrinsic afferent fiber groups that have selective termination areas (Frotscher and Leranth, 1985; Bakst et al., 1986; Wouterlood et al., 1990; Han et al., 1993; Maglóczky et al., 1994). To clarify the origins of axon terminals showing mGluR immunoreactivity in the hippocampus, we next generated various lesions in the sites of origin of the major hippocampal excitatory pathways.

First, massive unilateral lesions were placed in the entorhinal cortex to damage the perforant path, a major excitatory afferent path to the hippocampus (Amaral and Witter, 1995). In the rats with lesion involving most of the unilateral entorhinal cortex as well as a part of the adjacent perirhinal area and subicular complex (Fig. 7A-C,E,G, asterisks), immunoreactivity for mGluR1 and mGluR5 in the hippocampus ipsilateral to the lesion (Fig. $7 A, B$ ) was not different from that on the contralateral side (not shown). On the other hand, immunoreactivity for mGluR2/3, mGluR7a, and mGluR8 was markedly reduced ipsilaterally in the terminal zones of the perforant path (Fig. $7 \mathrm{C}-\mathrm{H}$ ). In the CA1 stratum lacunosum moleculare, the inner layer of CA3 stratum lacunosum moleculare, and the middle third of the dentate molecular layer, mGluR2/3 and mGluR7a immunoreactivity was greatly reduced (Fig. $7 C, E$ ). In the outer layer of $\mathrm{CA} 3$ stratum lacunosum moleculare and the outer third of the dentate molecular layer, mGluR7a and mGluR8 immunoreactivity was reduced (Fig. $7 E, G$ ). In a sector of CA1 near the CA1-CA2 transition, moderate mGluR2/3 immunoreactivity remained in stratum lacunosum moleculare (Fig. 7C, arrow). The mGluR2/3 labeling in this region, however, disappeared in the rats with massive lesions in the bilateral entorhinal cortices (not shown), indicating that mGluR2/3 immunoreactivity in this region originates not only from the ipsilateral but also from the contralateral entorhinal cortex. This observation is consistent with that of the previous tracer study showing the contralateral projection of the perforant path to the CA1 sector (Steward, 1976). Labeling for mGluR7a in the inner molecular layer remained intact (Fig. 7E). In accordance with the reduction of the mGluR7a immunoreactivity in neuropil, the decoration of interneuron dendrites in the molecular layer disappeared in the outer two-thirds of the layer but remained in the inner third of the layer (not shown). Moderate immunoreactivity for $\mathrm{mGluR} 7 \mathrm{a}$ also remained in a superficial 

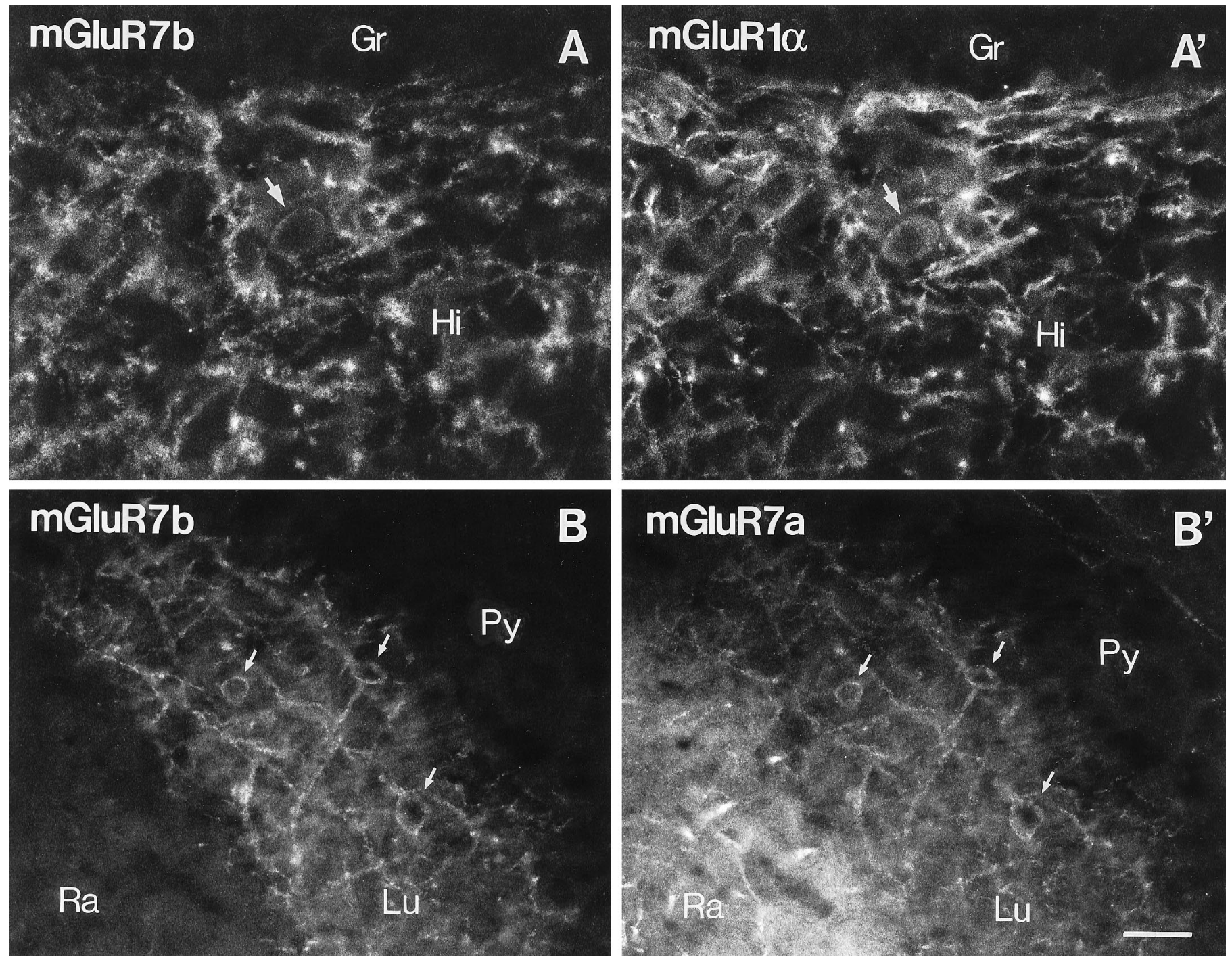

Figure 6. Double-immunofluorescence study for mGluR7b, mGluR1 $\alpha$, and mGluR7a in the hilus and CA3 stratum lucidum. Fluorescence micrographs of sections double-immunolabeled for mGluR7b and mGluR1 $\alpha\left(A, A^{\prime}\right)$ or mGluR7b and mGluR7a $\left(B, B^{\prime}\right)$ were taken from identical fields of the hilus $\left(A, A^{\prime}\right)$ and CA3 $\left(B, B^{\prime}\right)$ under different filters. Punctate immunolabeling for mGluR7b $(A$, visualized with Texas Red) decorates mGluR1 $\alpha$ immunopositive interneurons ( $A^{\prime}$, visualized with fluorescein) in the hilus $(H i)$. In CA3, all profiles decorated with mGluR7b $(B)$ are also decorated with mGluR7a immunoreactivity ( $B^{\prime}$, visualized with fluorescein) in stratum lucidum $(L u)$. Stratum radiatum $(R a)$ is immunopositive only for mGluR7a $\left(B^{\prime}\right)$. Arrows indicate cell bodies decorated with mGluR7a/b and labeled for mGluR1 $\alpha$ immunoreactivity. Gr, Granule cell layer; $P y$, pyramidal cell layer. Scale bar, $30 \mu \mathrm{m}$.

layer of CA1 stratum lacunosum moleculare in the ipsilateral hippocampus (Fig. 7E), which may suggest additional sources, such as the nucleus reuniens thalami (Wouterlood et al., 1990), for mGluR7a-immunoreactive afferent fibers in this layer. Thus, immunoreactivity for mGluR2/3, mGluR7a, and mGluR8 in the perforant path terminal zone originates mostly from the ipsilateral and partly from the contralateral entorhinal cortex.

\section{Effects of unilateral colchicine injection in the hilus on immunoreactivity for mGluRs in the hippocampus}

To examine the contribution of the dentate granule cells to the mGluR immunoreactivity in the hippocampus, we next used colchicine, which is known to preferentially degenerate the dentate granule cells (Goldschmidt and Steward, 1980). At the seventh day after unilateral colchicine injection $(3 \mu \mathrm{g}$ in $0.9 \mu \mathrm{l}$ of 25 mm PBS, $\mathrm{pH}$ 7.3) into the hilus of the dorsal and ventral hippocampus, a massive degeneration of the granule cells and moderate atrophy of the whole hippocampus were observed in the dentate gyrus ipsilateral to the injection (Fig. $8 A, B$ ). Immunoreactivity for mGluR1 and mGluR5 almost disappeared in the ipsilateral molecular layer, but was affected only slightly in the hilus and CA3 area (Fig. 8C,D, G,H). On the other hand, immunoreactivity for mGluR2/3, mGluR7a (Fig. 8I, arrows), and mGluR7b was markedly reduced in the ipsilateral mossy fiber terminal zone, namely, the hilus and CA3 stratum lucidum (Fig. $8 E, F, I-L)$, whereas $\mathrm{mGluR} 2 / 3$ labeling in the molecular layer was reduced only slightly (Fig. $8 E, F)$. Although immunoreactivity for mGluR7a was moderately reduced in the molecular layer (Fig. $8 I, J)$, the prominent labeling in the middle third of the layer was preserved. The reduction of mGluR7a immunolabeling was ob- 

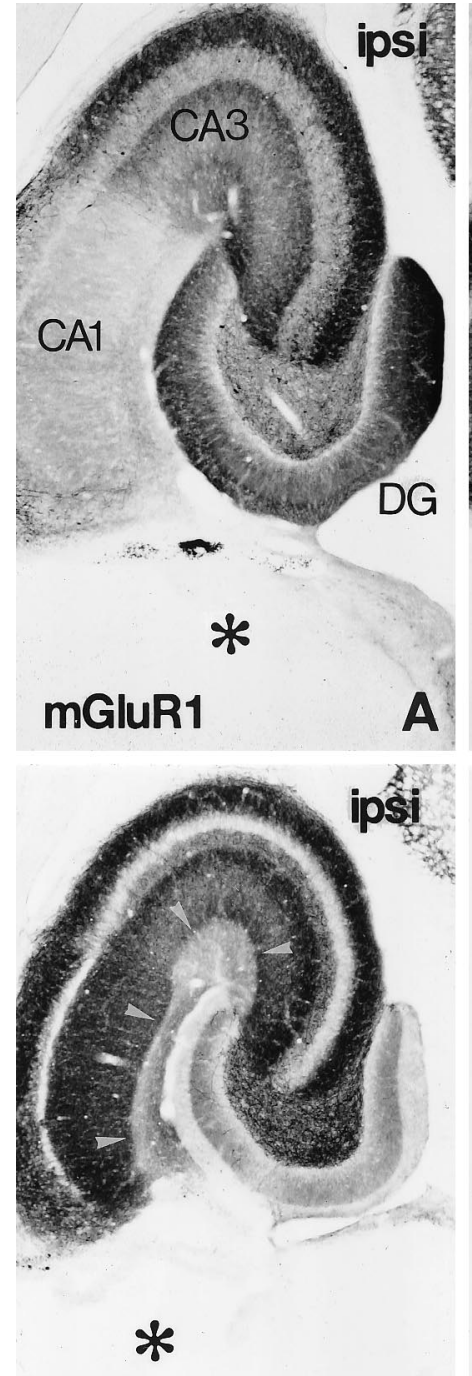

mGluR7a
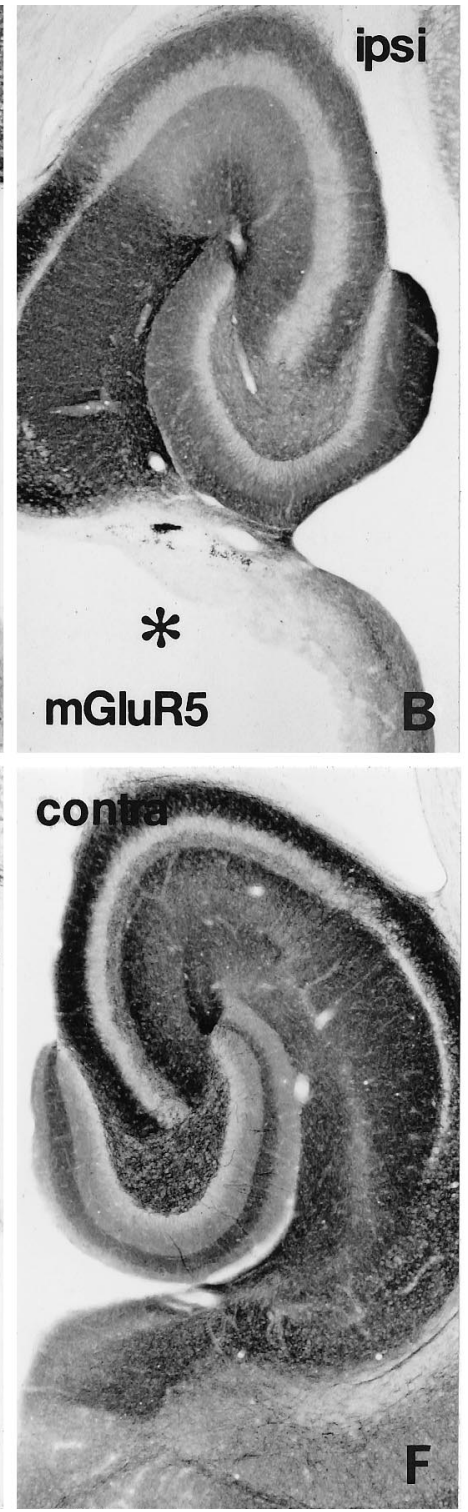
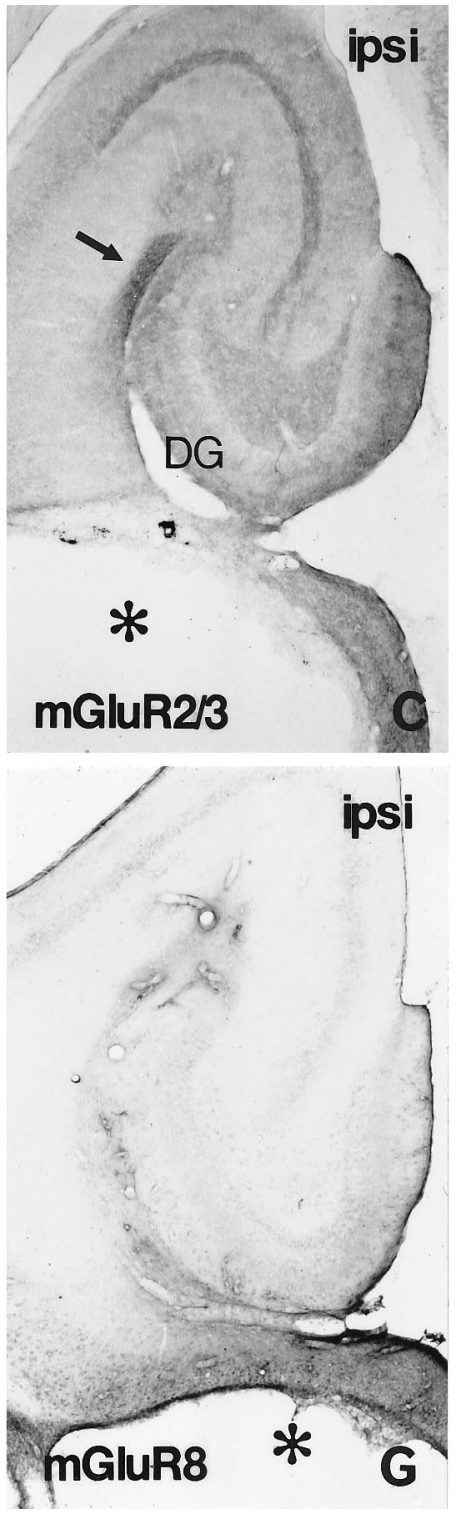
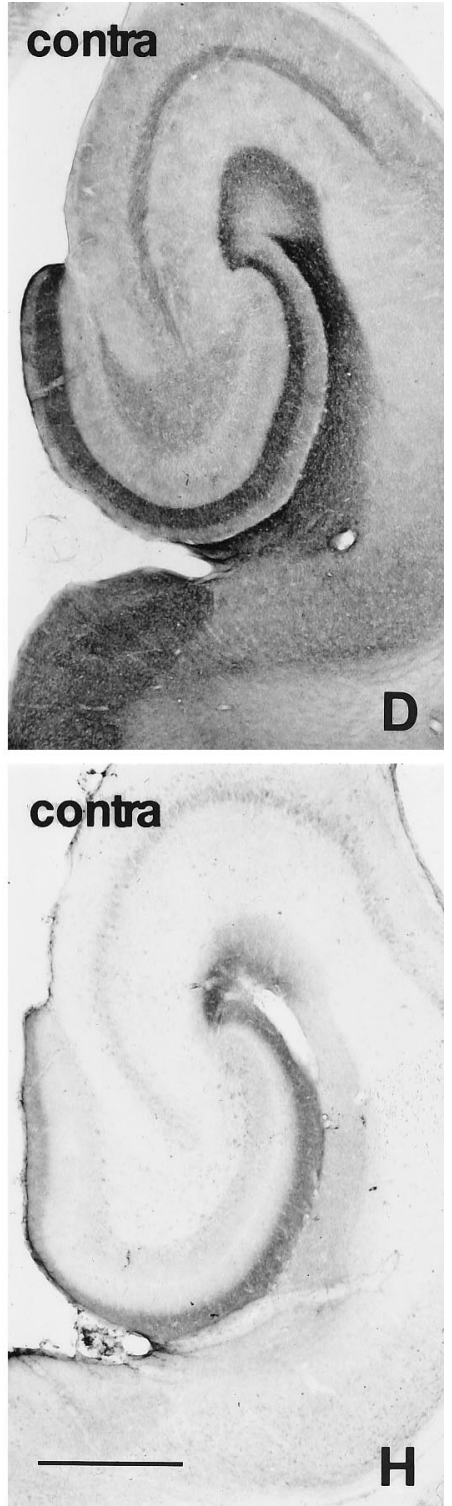

Figure 7. Distribution of immunoreactivity for mGluRs in the ipsilateral $(A-C, E, G)$ and contralateral $(D, F, H)$ hippocampus on the seventh day after placing a massive unilateral lesion in the perforant path. Adjacent horizontal sections were reacted with antibodies to mGluR1 $(A)$, mGluR5 $(B)$, mGluR2/3 $(C, D)$, mGluR7a $(E, F)$, and mGluR8 $(G, H)$. The lesion (asterisks) involves the entorhinal cortex and subiculum. Marked reduction of immunoreactivity for mGluR2/3 $(C)$, mGluR7a $(E)$, and mGluR8 $(G)$ is observed in the ipsilateral perforant path terminal zones of the CA areas, i.e., stratum lacunosum moleculare (arrowheads in $E$ ) and the molecular layer of the dentate gyrus $(D G)$. No apparent changes are found in immunoreactivity for mGluR1 or mGluR5 $(A, B)$. An mGluR2/3 immunoreactive area remains (arrow in $C$ ) in CA1 stratum lacunosum moleculare near CA1-CA2 transition. ipsi, Ipsilateral to the lesion; contra, contralateral to the lesion. Scale bar, $500 \mu \mathrm{m}$.

served in the decoration of the dendritic profiles as well as in neuropil.

\section{Effects of local and intraventricular kainate injections on immunoreactivity for mGluRs in the hippocampus}

It has been known that local kainate injection degenerates only postsynaptic elements in the injection site (Coyle and Schwarcz, 1976) and that intraventricular kainate injection selectively degenerates $\mathrm{CA} 3$ pyramidal cells in the hippocampus (Nadler et al., 1980). At the seventh day after the local kainate injections into the CA3 area $(0.2 \mu \mathrm{g}$ in $0.2 \mu \mathrm{l}$ of PBS), pyramidal cells in the restricted regions degenerated with gliosis (Fig. 9A). Immunoreactivity for mGluR1 and mGluR5 was markedly reduced in the dendritic fields of the degenerative pyramidal cells (Fig. 9B,D), whereas that for mGluR2/3 and mGluR7a was unaffected (Fig.
$9 C, E)$. The local kainate injection directed to CA1 pyramidal cells also reduced mGluR5 immunoreactivity but not mGluR7a immunoreactivity in the dendritic fields of the degenerative pyramidal cells (data not shown). After the bilateral kainate injection $(0.6 \mu \mathrm{g}$ in $1.2 \mu \mathrm{l}$ of PBS), severe epileptic response was observed for several hours, as reported previously (Nadler et al., 1980). At the seventh day after the injection, massive degeneration of CA3 pyramidal cells and hilar neurons was observed bilaterally, with most of the CA1 pyramidal cells and granule cells being preserved (Fig. $9 F$ ). Some interneurons, including those in CA1 stratum oriens/alveus, also disappeared, as clearly shown by the lack of the dense mGluR1-immunoreactive dendritic plexus (Fig. $9 G$, open arrows; also see Fig. $2 A$ ). This might be ascribable to susceptibility of these neurons to excitotoxicity after prolonged 


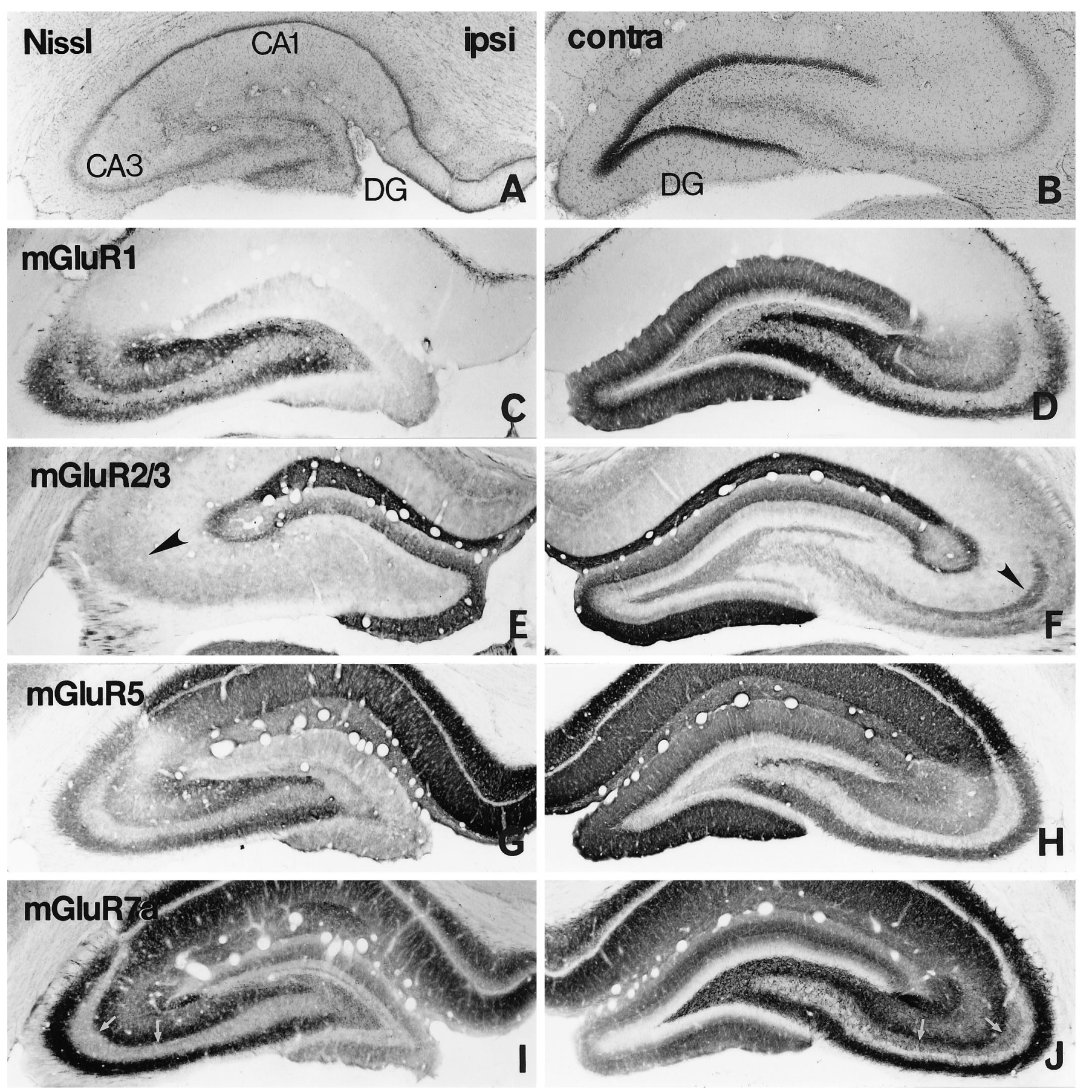

\section{mGluR7b}

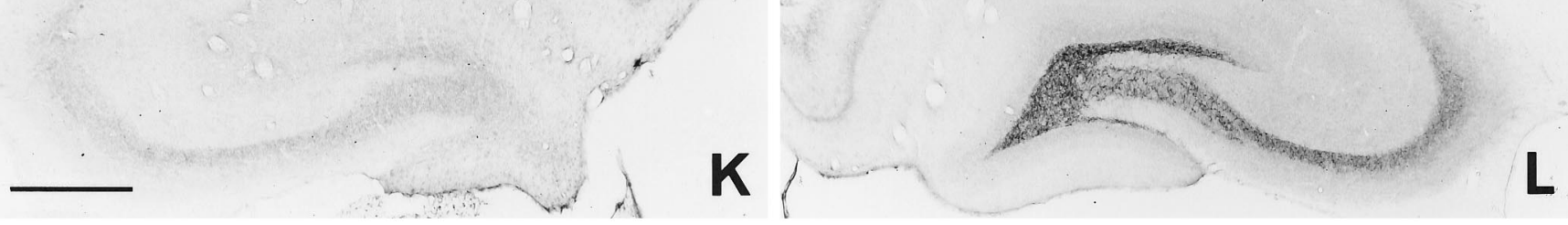

Figure 8. Effects of unilateral colchicine injection into the hilus on immunoreactivity for mGluRs in the ipsilateral $(A, C, E, G, I, K)$ and contralateral $(B, D, F, H, J, L)$ hippocampus. Adjacent frontal sections were reacted with antibody to mGluR1 $(C, D)$, mGluR2/3 $(E, F)$, mGluR5 $(G, H)$, mGluR7a $(I, J)$, or mGluR7b $(K, L)$. Massive degeneration of granule cells in the dentate gyrus $(D G)$ ipsilateral to the colchicine injection is seen in Nissl-stained sections $(A, B)$. On the seventh day after the colchicine injection, marked reduction of immunoreactivity for mGluR1 $(C)$ and mGluR5 $(G)$ is observed in the dentate molecular layer ipsilateral to the lesion, whereas marked reduction of immunoreactivity for mGluR2/3 (arrowhead in $E$ ), mGluR7a (arrows in $I$ ), and mGluR7b $(K)$ is observed in the ipsilateral mossy fiber terminal zone. Scale bar, $500 \mu \mathrm{m}$. 
stimulation (cf. Ouardouz and Lacaille, 1995). Immunoreactivity for mGluR1 and mGluR5 in the hilus and dendritic fields of CA3 pyramidal cells was also markedly reduced (Fig. 9G,I). In CA1 strata oriens and radiatum, which are the dendritic fields receiving Schaffer collaterals from CA3 pyramidal cells, mGluR5 immunoreactivity remained intact (Fig. 9I), whereas mGluR7a immunoreactivity was markedly reduced (Fig. 9J). Labeling for mGluR7a was also reduced in CA1 stratum lacunosum moleculare (Fig. 9J, arrows) but not in CA3 stratum lacunosum moleculare and the middle third of the dentate molecular layer (Fig. 9J). The same pattern of reduced immunostaining in the perforant path terminal zone was also apparent for mGluR2/3 immunoreactivity (Fig. $9 H$, arrows). This effect of the bilateral intraventricular kainate injection is probably attributable to preferential degeneration of the entorhinal layer III neurons (Nadler et al., 1980) projecting to CA1 stratum lacunosum moleculare (Steward and Scoville, 1976). In fact, Nissl staining showed massive degeneration of neurons in layer III but not in layer II of the entorhinal cortex (data not shown). No changes in immunoreactivity for mGluR2/3 and mGluR7a were detected in CA3 stratum lacunosum moleculare and the outer two-thirds of the dentate molecular layer, which receive projection fibers from layer II neurons (Steward and Scoville, 1976). In the inner third of the molecular layer, labeling for mGluR7a appeared to be reduced, probably because of loss of associational/commissural projections from the hilar neurons (Amaral and Witter, 1995). Immunoreactivity for mGluR2/3 and mGluR7a in the mossy fiber terminal zone remained (Fig. 9H,J), despite the massive degeneration of postsynaptic elements in this region.

\section{Localization of immunoreactivity for mGluRs as detected by electron microscopy}

As a final step, we performed immunoelectron microscopy in the hippocampus with the antibodies for mGluR2/3, mGluR2, mGluR4a, mGluR7a, mGluR7b, and mGluR8 (Figs. 10-13). The previous study revealed that immunolabeling for mGluR1 and mGluR5 in neuropil of the CA areas is attributable to staining of dendrites and dendritic spines of pyramidal and granule cells (Luján et al., 1996). Immunoreactivity for the group I mGluRs in presynaptic elements, however, was not detected in the hippocampus. In the present study, immunolabeling for all of the group II/III mGluRs was observed in presynaptic elements, with differential patterns of location between the group II and group III mGluRs.

Immunoreactivity for mGluR2/3 was frequently found in small unmyelinated axons, especially in preterminal rather than terminal portions of axons, and most densely in CA1 lacunosum moleculare (Fig. 10 A, C). Even in axon terminals, peroxidase and immunogold labelings were often found along extrasynaptic membrane and only rarely detected in the presynaptic membrane specialization. Labeling detected with the mGluR2 antibody, which was raised against amino acid residues 87-134, was found in the extracellular space (Fig. 10B), supporting the predicted transmembrane model for mGluRs (Masu et al., 1991). This situation sometimes made it difficult to decide which side of the space was the site of the immunoreaction. In many cases, however, the peroxidase reaction end product accumulated along the surface of small unmyelinated axons and terminals in CA1 lacunosum moleculare (Fig. 10B). Around terminals, mGluR2 labeling was not detected in the synaptic clefts, confirming the results obtained with the mGluR2/3 antibody. In CA3 stratum lucidum, immunoreactivity for mGluR2/3 was often observed in axon bundles of the mossy fibers (Fig. 10D) and occasionally in the giant mossy fiber terminals, but again was not associated with the presynaptic junctional sites. The mGluR2/3 labeling in the axons seemed to be concentrated on certain spots rather than distributed evenly along the axonal membrane. Glial processes were also immunopositive for mGluR2/3 everywhere in the hippocampus (Fig. 10E), probably reflecting a cross-reactivity of the antibody to mGluR3 (Ohishi et al., 1994). Consistently, mGluR3 mRNA expression was also observed in glial cells in the hippocampus (Ohishi et al., 1993b)

Ultrastructural localization of immunoreactivity for the group III mGluRs had quite a different pattern from that for mGluR2/3. Peroxidase reaction end products for mGluR4a, mGluR7a, mGluR7b, and mGluR8 were predominantly present in axon terminals, often attached to the presynaptic sites of asymmetrical and symmetrical synapses in the hippocampus (Figs. 11-13). Immunogold particles for these mGluRs were concentrated in the presynaptic membrane specialization (Figs. $11 B, 12 C$, and inset to Fig. 13B). Peroxidase reaction products also accumulated less frequently in axonal profiles, and single immunoparticles were found occasionally on axonal membranes.

In the dentate molecular layer, terminals making asymmetrical synapses on spines were immunoreactive for mGluR4a (Fig. 11A), mGluR7a, and mGluR8 (Fig. 13A). Most of the asymmetrical synapses on spines of granule cells are formed by perforant path terminals in the outer molecular layer (Matthews et al., 1976) and by associational/commissural terminals in the inner one-third of the layer (Kishi et al., 1980). Less frequently, symmetrical synapses on dendrites were also labeled for mGluR4a (Fig. 11C), mGluR7a, and mGluR8. The decoration of dendritic profiles observed with light microscopy (Fig. 4) originated from many immunopositive terminals making asymmetrical synapses on dendrites of interneurons (Fig. 13B). Virtually all of the terminals making asymmetrical synapses on the particular interneurons were immunopositive for mGluR7a, whereas the proportion of immunopositive terminals was lower for the decoration with mGluR4a and mGluR8. A few terminals with labeled symmetrical synapses were also in contact with the decorated dendrites. Occasionally, axon terminals with labeled asymmetrical synapses on the decorated dendrites made other, unlabeled asymmetrical synapses on spines. The segregation of receptors in single terminals was also apparent between two synapses on dendrites (Figs. 11D, 13D). Although the identity of the postsynaptic dendrites receiving labeled and unlabeled synapses remains elusive, they seemed to originate from different interneurons.

In the dendritic fields of the CA areas, large numbers of asymmetrical synapses on spines were immunoreactive for mGluR7a (Fig. 12A). The decoration of somatodendritic profiles with many intensely labeled asymmetrical synapses was scattered in the CA areas, as described previously (Bradley et al., 1996; Shigemoto et al., 1996). For mGluR4a and mGluR8, labeled synapses decorated dendrites (Fig. 11B) and cell bodies (Fig. $13 C$ ) only occasionally in the CA areas. In CA3 stratum lucidum and hilus, immunoreactivity for mGluR7a and mGluR7b was observed in numerous small axon terminals surrounding dendrites and long spines (Fig. 12C) of interneurons with asymmetrical synapses. Labeling was found much less frequently in symmetrical synapses on dendrites (Fig. 12D). On the other hand, cell bodies of the interneurons were surrounded by many mGluR7a/ b-labeled symmetrical synapses (Fig. 12B). Occasionally, labeling was found in the giant mossy fiber terminals; however, reaction end products were accumulated only in the presynaptic sites to presumed mGluR $1 \alpha$-positive interneuron dendrites but not in the presynaptic sites to CA3 pyramidal cell spines (Fig. 12E). 

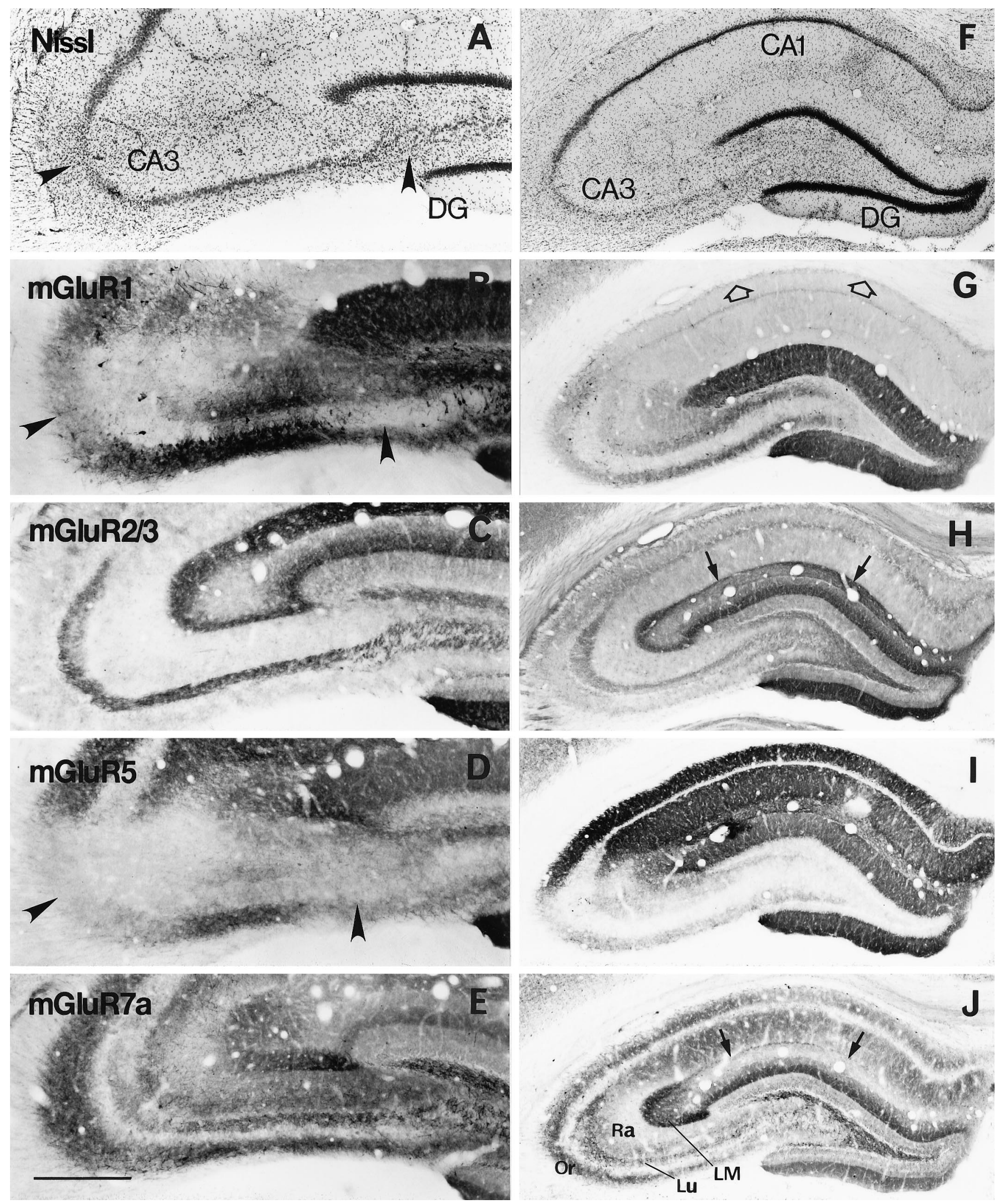

Figure 9. Effects of small unilateral injection $(A-E)$ and bilateral intraventricular injection $(F-J)$ of kainate on immunoreactivity for mGluRs in the hippocampus. A small amount of kainate $(0.2 \mu \mathrm{g}$ in $0.2 \mu \mathrm{l}$ of PBS) was injected into two small areas in CA3, resulting in degeneration of CA3 pyramidal cells in the restricted areas as shown with Nissl staining (arrowheads in $A)$. A larger amount of kainate $(0.6 \mu \mathrm{g}$ in $1.2 \mu \mathrm{l}$ of PBS) was injected into bilateral ventricles to make massive bilateral degeneration of CA3 pyramidal cells, with most CA1 pyramidal cells being preserved $(F)$. Adjacent frontal sections were reacted with antibodies to mGluR1 $(B, G)$, mGluR2/3 $(C, H)$, mGluR5 $(D, I)$, or mGluR7a $(E, J)$. On the seventh day $($ Figure legend continues $)$ 


\section{DISCUSSION}

The present study revealed the differential distribution of presynaptic mGluRs in the major excitatory pathways in the hippocampus (Table 1 ). Type $2 / 7 \mathrm{a} / 8$, type $2 / 7 \mathrm{a} / 7 \mathrm{~b}$, and type $7 \mathrm{a}$ mGluRs are localized in the perforant path, mossy fibers, and Schaffer collaterals, respectively. Electron microscopy further revealed predominant localization of group II and group III mGluRs in the extrasynaptic and synaptic sites, respectively. Finally, each group III receptor in individual synapses of single presynaptic elements was found to be segregated in correlation with postsynaptic target neurons.

\section{Presynaptic mGluRs in the hippocampal pathways}

Massive degeneration of postsynaptic elements after lesions may induce morphological changes in presynaptic elements in the same region (Nadler et al., 1981), and vice versa (Matthews et al., 1976). Nonetheless, in the present study, complementary results obtained with lesions of pre- and postsynaptic elements unequivocally indicated the major origins of mGluR immunoreactivity in the hippocampus. For example, the kainate injection into CA1 depleted mGluR5 immunoreactivity in the dendritic fields of the degenerated pyramidal cells but had no effect on mGluR7a immunoreactivity. Conversely, extensive lesions made in the entorhinal cortex or CA3 reduced mGluR 7 a immunoreactivity in CA1 terminal zones that receive fibers from the degenerated regions, but exerted no effects on mGluR5 immunoreactivity. These results clearly indicate that immunoreactivity for mGluR5 and mGluR7a in CA1 originates primarily from pyramidal cell dendrites and perforant path/Schaffer collateral axons, respectively.

In the perforant path terminating in the CA3 area and the dentate gyrus, we found complementary localization of mGluR2 and mGluR8 being enriched in the medial and lateral perforant path, respectively. Consistent with this finding, expression of mGluR2 and mGluR8 mRNAs was prominent in layer II of the medial and lateral entorhinal cortex, respectively (Ohishi et al., 1993a; A. Kinoshita, unpublished observation). DCG-IV potently reduced field excitatory postsynaptic potentials in the medial but not in the lateral perforant path, whereas micromolar concentrations of L-AP4 reduced those in the lateral but not in the medial perforant path (Macek et al., 1996). These electrophysiological data are compatible with the complementary localization of mGluR2 and mGluR8 in the dentate molecular layer. Enrichment of mGluR7a in the medial perforant path also agrees with the inhibitory effect of millimolar concentrations of L-AP4 in this path (Koerner and Cotman, 1981; Macek et al., 1996) because mGluR7a has an exceptionally high $\mathrm{EC}_{50}$ value $(1 \mathrm{~mm})$ for glutamate (Okamoto et al., 1994). Although mRNA for mGluR4 is strongly expressed in layers II and III of the entorhinal cortex (Saugstad et al., 1994; Ohishi et al., 1995a), mGluR4a immunoreactivity was not clearly detected in the perforant path terminal zones in the present study. This may be attributable to the preferential expression of another splice variant mGluR4b
(Thomsen et al., 1997) in this pathway; however, mGluR4 may not be involved in the synaptic depressant effects in the lateral perforant path, because different pharmacology was found between cloned mGluR4a and L-AP4-sensitive receptors mediating such effects (Johansen et al., 1995). In fact, no changes were observed in the L-AP4 effects on this pathway in mGluR4deficient mice (Baskys et al., 1996).

Labeling for mGluR4a was found in asymmetrical synapses on spines and dendrites and in symmetrical synapses on dendrites in the inner one-third of the molecular layer, which receives projections from neurons in the hilus (Amaral and Witter, 1995), septal cholinergic neurons (Frotscher and Leranth, 1985), and supramammillary neurons (Maglóczky et al., 1994). The mossy cells in the hilus and supramammillary neurons make asymmetrical synapses with granule cells (Maglóczky et al., 1994; Buckmaster et al., 1996), but mGluR4 mRNA is strongly expressed only in the hilus (Ohishi et al., 1995a), supporting the mossy cells as the origin of the mGluR4a-labeled axon terminals. Axon terminals making both mGluR4a-labeled symmetrical synapses and unlabeled asymmetrical synapses may originate from septal cholinergic neurons, because they form both types of synapses in the dentate gyrus (Frotscher and Leranth, 1985).

In the mossy fiber synapses on CA3 pyramidal cells, DCG-IV but not L-AP4 suppressed excitatory transmission in the rat (Lanthorn et al., 1984; Yokoi et al., 1996). This effect was reduced to $\sim 50 \%$ of the control level in mice lacking mGluR2 (Yokoi et al., 1996), indicating the involvement of mGluR2 as well as other DCG-IV-sensitive receptors. In the present study, mGluR7a and mGluR7b were found in the mossy fiber but not in synapses on CA3 pyramidal cells. They are present almost exclusively in synapses on mGluR $1 \alpha$-positive interneurons, which correspond to somatostatin/GABA-immunoreactive interneurons (Baude et al., 1993). These interneurons are heavily innervated by mossy fiber collaterals (Leranth et al., 1990), and virtually all asymmetrical synapses made on the interneurons had high densities of mGluR7a/b, showing up as almost continuous profiles of dendrites in light microscopy (Fig. 6). Cell bodies also showed up with many symmetrical synapses labeled for mGluR7a/b. The somatostatin-immunoreactive interneurons constitute symmetrical synapses on their cell bodies and dendrites with septal cholinergic (Leranth and Frotscher, 1987) and GABAergic (Milner and Bacon, 1989) axon terminals, and mGluR7 mRNA is strongly expressed in the medial septal and hilar neurons (Ohishi et al., 1995a). Smaller numbers of symmetrical synapses on interneurons were also labeled for mGluR4a and mGluR8 in the present study. Although depression of inhibitory synaptic transmission is mediated by group II mGluRs in the hippocampal pyramidal cells (Poncer et al., 1995), no such effects mediated by group III mGluRs have been reported so far.

Several lines of evidence have suggested that group I and III mGluRs are involved in presynaptic inhibition of excitatory trans-

$\leftarrow$

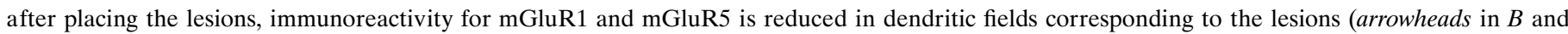

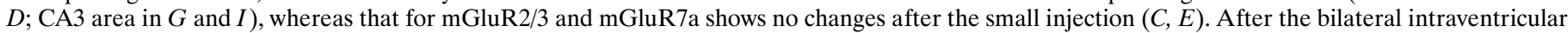

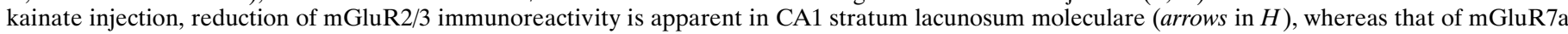

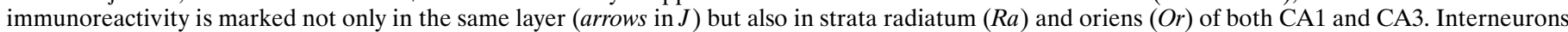

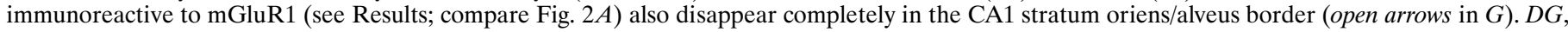
Dentate gyrus; $L M$, stratum lacunosum moleculare; $L u$, stratum lucidum. Scale bars: $250 \mu \mathrm{m}$ for $A-E ; 500 \mu \mathrm{m}$ for $F-J$. 

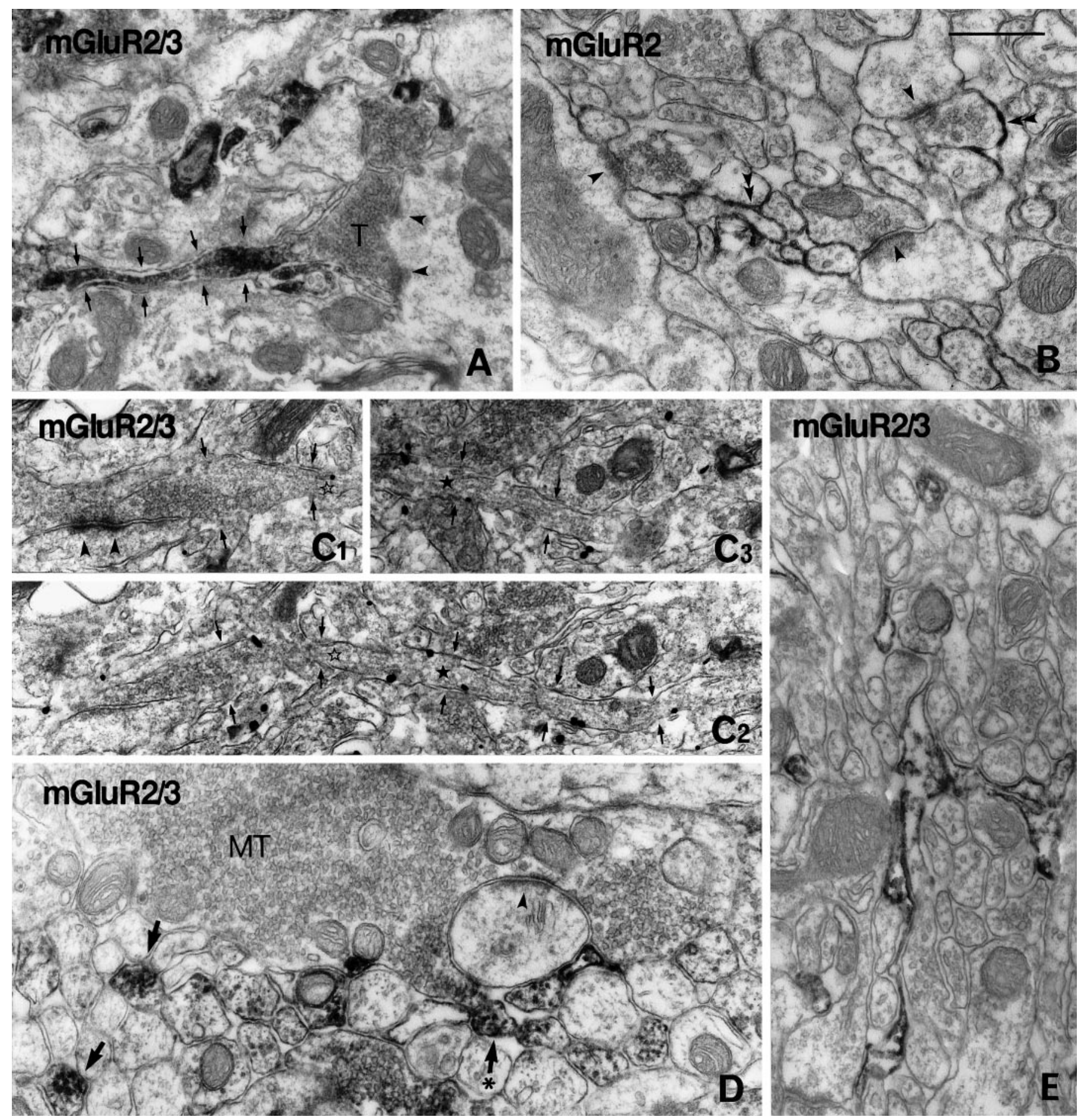

Figure 10. Electron micrographs showing immunoreactivity for mGluR2/3 $(A, C, D, E)$ and mGluR2 $(B)$ in CA1 stratum lacunosum moleculare $(A-C)$, CA3 stratum lucidum $(D)$, and CA1 stratum radiatum $(E)$ as detected by preembedding immunoperoxidase $(A, B, D, E)$ and immunogold $(C)$ methods. $A$, Peroxidase reaction product for mGluR2/3 is accumulated intracellularly in a preterminal axon (arrows), which is continuous to an unlabeled axon terminal making asymmetrical synapses (arrowheads). B, Peroxidase reaction product for mGluR2 is accumulated extracellularly along axons and axon terminals (double arrowheads), but not in the synaptic clefts of asymmetrical synapses (arrowheads). C1, C2, and C3 were taken from three serial sections. Silver-enhanced immunogold particles for mGluR2/3 are found along a preterminal axon (arrows), which is continuous to an axon terminal making unlabeled asymmetrical synapses (arrowheads). Open and closed stars indicate corresponding regions in the serial sections. D, Peroxidase labeling for mGluR2/3 is observed in mossy fibers (arrows), one of which (asterisk) is continuous to a giant mossy fiber terminal (MT) making unlabeled asymmetrical synapses (arrowhead) with spines of CA3 pyramidal cells. E, Glial processes are also labeled for mGluR2/3. Scale bar, $0.5 \mu \mathrm{m}$.

mission from Schaffer collaterals to CA1 pyramidal cells in the adult rat (Gereau and Conn, 1995a; Manzoni and Bockaert, 1995). In the Schaffer collateral terminal zones in CA1, mGluR5 and mGluR7a immunoreactivity was strongly detected in the present study. Although the presynaptic location of mGluR7a is consistent with the reported effects of millimolar concentrations of L-AP4, we found no evidence for the presence of presynaptic mGluR5 (also see Luján et al., 1996). It should be noted, how- 

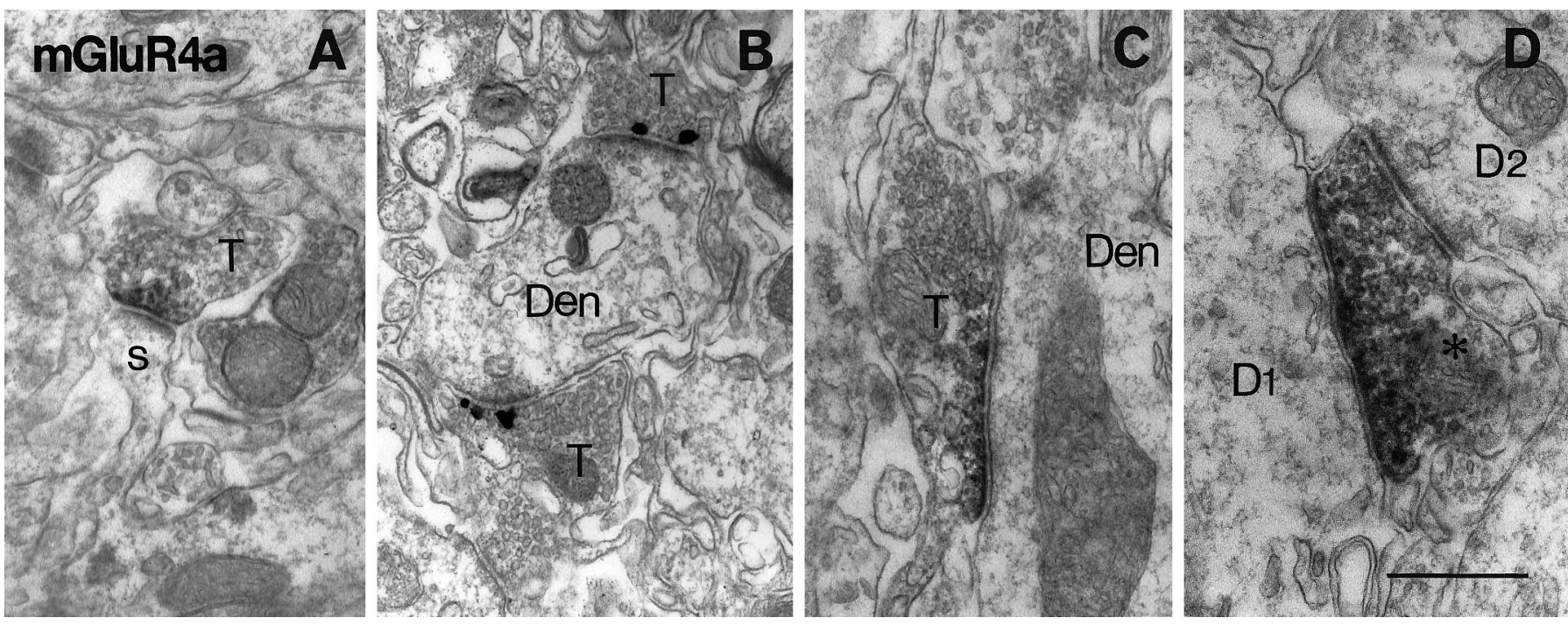

Figure 11. Electron micrographs showing immunoreactivity for mGluR4a in the inner third of the dentate molecular layer $(A, C, D)$ and in CA2 stratum oriens $(B)$. Peroxidase $(A, C, D)$ and immunogold $(B)$ labeling for mGluR4a is found in presynaptic membrane specialization of asymmetrical synapses $(A, B)$ on spines $(s)$ and dendrites $(D e n)$ or symmetrical synapses $(C, D)$ on dendrites $(D e n, D 1)$. The labeled axon terminal $($ asterisk in $D)$ in symmetrical synaptic contact with $D 1$ makes another unlabeled asymmetrical synapse on another dendrite $(D 2)$. $T$, Axon terminal. Scale bar, $0.5 \mu$ m.

ever, that the inhibitory effect of DHPG depends on NMDA receptor activation in these synapses (Harvey et al., 1996). This finding raises the possibility of a synergistical mechanism involving postsynaptic mGluR5 and NMDA receptors to depress presynaptic glutamate release through another messenger, such as adenosine (Manzoni et al., 1994; Di Iorio et al., 1996) or nitric oxide (Boulton et al., 1994).

\section{Extrasynaptic versus synaptic localization of group II and group III mGluRs}

One of the most striking observations in the present study is the segregation of group II and group III mGluRs in presynaptic elements. The difference in mGluR localization in relation to glutamate release sites suggests that effector mechanisms as well as the sources of glutamate activating these receptors may be distinct from each other. It is conceivable that the group III mGluRs in the presynaptic active zone act as autoreceptors activated with glutamate released from the very synapse to which the receptors are localized. Patch-clamp recordings from the presynaptic terminals directly indicated that L-AP4-sensitive mGluRs are coupled to P/Q-type voltage-sensitive calcium channels to suppress excitatory postsynaptic currents in the trapezoid body nucleus (Takahashi et al., 1996). In the present study, the group III mGluRs were found also in symmetrical synapses, which have much lower glutamate concentrations than asymmetrical synapses in the hippocampus (Bramham et al., 1990). For such nonglutamatergic synapses, a major question would be the source of glutamate that activates the presynaptic mGluRs. GABA release may be inhibited by glutamate spilled over from nearby synapses (Hayashi et al., 1993; Ohishi et al., 1994) or released from dendrosomatic regions (Glitsch et al., 1996). The functional significance of presynaptic mGluR7a/b in nonglutamatergic synapses is unclear, however, because it is unlikely that receptors with such a low affinity to glutamate are activated by diluted signals from remote synapses.

In contrast to group III mGluRs enriched at synaptic sites, mGluR2 is mainly localized apart from synaptic sites. Localization of mGluR3 in neuronal cells is inconclusive in the present study; only a small portion of mGluR $2 / 3$ immunoreactivity is ascribable to mGluR3 because of weak cross-reactivity of this antibody to mGluR3 (Hayashi et al., 1993). Extrasynaptic mGluR2 may be activated not only with glutamate released from homologous presynaptic elements but also with glutamate from heterologous presynaptic elements that make asymmetrical synapses near the mGluR2-bearing axons. Recent studies showed that glutamate accumulated by repeated stimulations with short intervals, but not by single stimulations, activates presynaptic group II mGluRs in mossy fibers to induce long-term depression (Yokoi et al., 1996) and to suppress excitatory transmission (Scanziani et al., 1997). Although these studies are suggestive of the autoreceptor function for $\mathrm{mGluR2}$, it is also possible that mGluR2 is activated by prolonged glutamate release from nearby synapses to cause heterosynaptic interaction. For the effectors of group II mGluRs, N- and L-type calcium channels were reported in cultured hippocampal neurons (Sahara and Westbrook, 1993) and in heterologous expression systems (Ikeda et al., 1995). Each type of neuron, however, expresses a distinct set of calcium channel subtypes in certain subcellular compartments (Sakurai et al., 1996), and it is not clear whether mGluR2 is coupled to these channels in the preterminal axons. An alternative possible effector mechanism for the axonal mGluR is reducing efficacy of axonal signal transmission by facilitating potassium channels. In the perforant path, which was most strongly labeled for mGluR2 in the present study, voltage-dependent potassium channel subunits Kv1.2/1.4 (Sheng et al., 1993) and G-protein-coupled inwardly rectifying potassium channels (Ponce et al., 1996) are abundant, and the latter is efficiently coupled to mGluR2 in a Xenopus oocyte expression system (Saugstad et al., 1996). Highresolution colocalization of mGluR2 and these channel/effector molecules in axons would help to clarify the physiological implication of this receptor.

\section{Target-specific segregation of group III mGluRs in single axons}

A target cell-specific concentration of receptor proteins in the presynaptic active zone was first reported for mGluR7a in the 

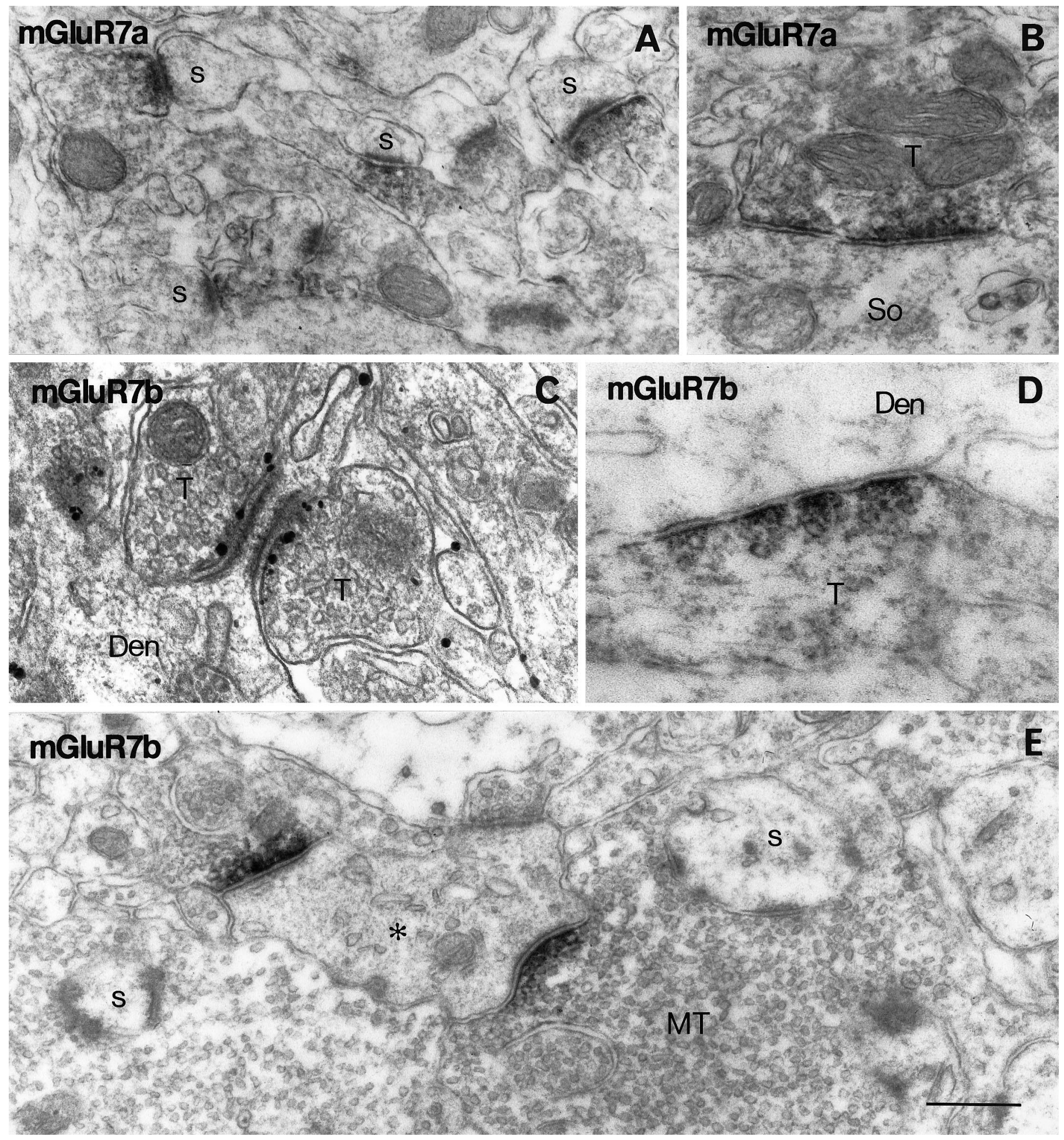

Figure 12. Electron micrographs showing immunoreactivity for mGluR7a $(A, B)$ and mGluR7b $(C-E)$ in CA1 stratum radiatum $(A)$, hilus $(B)$, and CA3 stratum lucidum $(C-E)$. Peroxidase reaction product for mGluR7a is accumulated along presynaptic membrane specialization of asymmetrical synapses on spines $(s)$ of CA1 pyramidal cells $(A)$ and symmetrical synapses on a soma $(S o)$ in the hilus $(B)$. Immunogold particles for mGluR $7 \mathrm{~b}$ are concentrated in presynaptic membrane specialization of asymmetrical synapses on dendrites and necks of long spines $(C)$. Symmetrical synapses on a dendrite $(D e n)$ are also labeled for mGluR7b $(D)$. Note that the accumulation of the peroxidase reaction product is restricted to active zones of presynaptic membrane $(D)$. E, A giant mossy fiber terminal $(M T)$ makes a labeled synapse on a dendritic profile (asterisk) of a presumed interneuron and also makes unlabeled synapses on spines $(s)$ of CA3 pyramidal cells. $T$, Axon terminal. Scale bars: $0.5 \mu \mathrm{m}$ for $A, B ; 0.26 \mu \mathrm{m}$ for $C, D ; 0.4 \mu \mathrm{m}$ for $E$. 

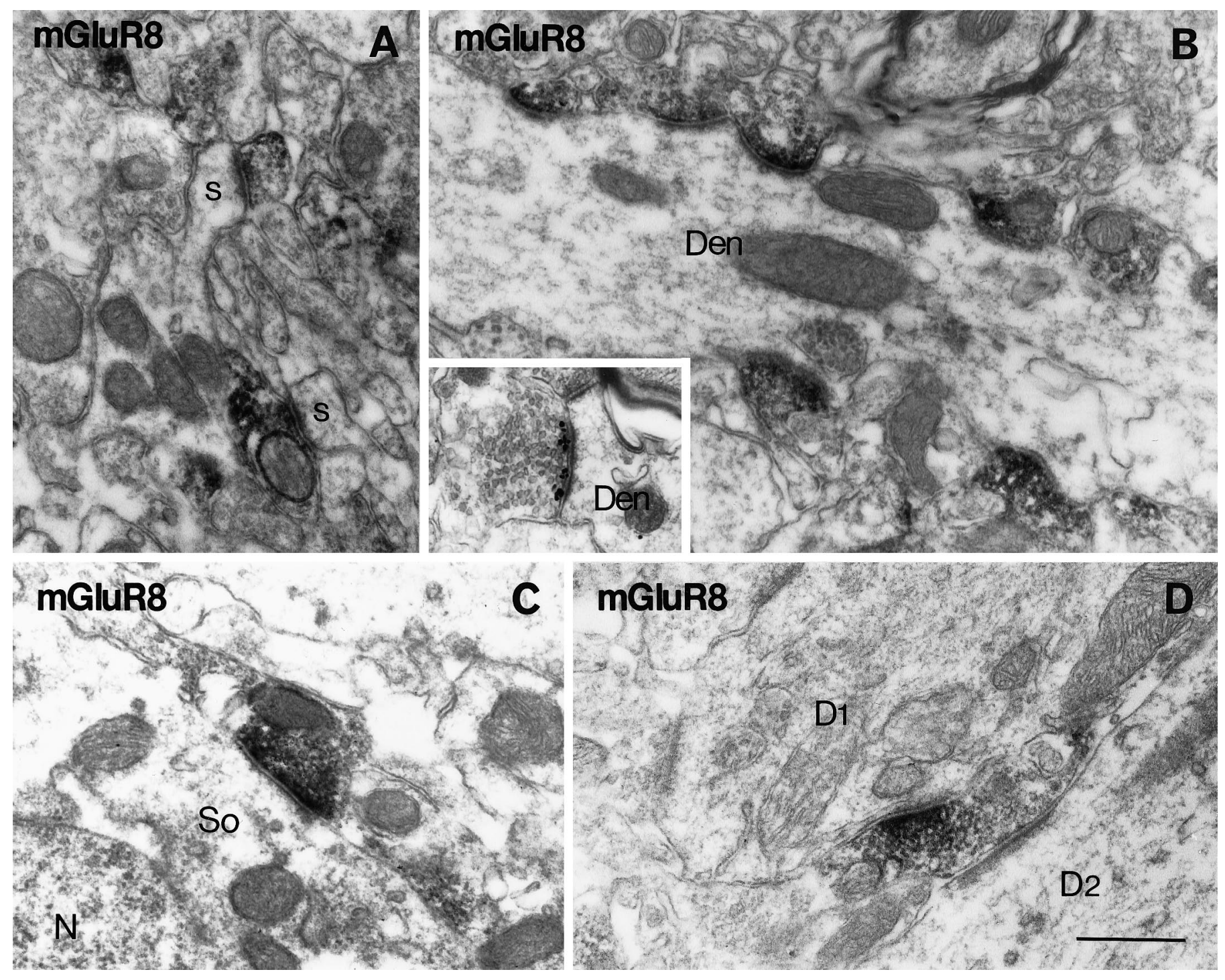

Figure 13. Electron micrographs showing immunoreactivity for mGluR8 in the dentate molecular layer $(A, B, D)$ and CA2 stratum oriens $(C)$. Peroxidase reaction product is accumulated in axon terminals, which make asymmetrical synapses on spines $(s$ in $A)$ or dendrites $(D e n$ in $B ; D 1$ in $D)$ or a symmetrical synapse on a soma $(S o$ in $C$ ). Inset in $B$ indicates immunogold labeling for mGluR8 concentrated in presynaptic membrane specialization. Most of the asymmetrical synapses on the dendritic profile are labeled in $B$. The axon terminal in $D$ makes a labeled asymmetrical synapse on a dendrite $(D 1)$ and an unlabeled asymmetrical synapse on another dendrite $(D 2)$. Scale bar, $0.5 \mu \mathrm{m}$.

\begin{tabular}{llllll}
\hline \multicolumn{6}{l}{ Table 1. Distribution of immunoreactivity for presynaptic mGluRs in excitatory pathways in the hippocampus } \\
Subtype & PP (CA1) & PP (CA3) & PP (DG) & MF & A/C (CA3) \\
\hline mGluR2 & +++ & ++ (medial) & ++ (medial) & ++ & - \\
mGluR7a & ++ & +++ (medial) & $++($ medial) & $+^{a}$ & ++ \\
mGluR7b & - & ++ (lateral) & + (lateral) & & - \\
mGluR8 & - & - & - & $++^{a}$ & - \\
\hline
\end{tabular}

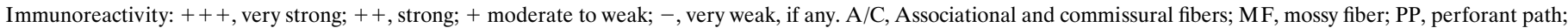
Sch, Schaffer collateral. Medial, lateral: prominent in medial or lateral perforant path terminal zone.

${ }^{a}$ Immunoreactivity is mostly present in synapses on interneurons.

hippocampus (Shigemoto et al., 1996). This type of receptor segregation seems to be a general feature of the group III mGluRs. In the present study, mGluR7b was concentrated, even more exclusively than mGluR7a, in synapses making contacts with presumed mGluR $1 \alpha$-positive interneurons in the mossy fiber terminal zone. Synapses on CA3 pyramidal cells made by the same mossy fiber had very little labeling for mGluR7b. Not only glutamatergic synapses but also nonglutamatergic synapses on cell bodies of the mGluR $1 \alpha$-positive interneurons were labeled for $\mathrm{mGluR7a} / \mathrm{b}$. Although it is not known whether nonglutama- 
tergic neurons also locate these receptors according to distinct targets along single axons, this finding is suggestive of some postsynaptic influence common to axon terminals of different types. A similar segregation according to postsynaptic targets was found for mGluR4a and mGluR8, but not all of the synapses on the interneurons were labeled. This may be attributable to the lack of expression of these mGluRs in some neurons providing afferents to those interneurons, or to unknown local third factor(s) governing the selective distribution of these mGluRs in individual synapses. In any case, such a segregation should be regulated in a spatially restricted way, probably through nondiffusable membrane-bound molecules. Different regulation of transmitter release mediated by L-AP4-sensitive mGluRs may result in differential transmission of time-coded signals to principal neurons and to interneurons (Shigemoto et al., 1996). In mGluR4- and mGluR7-deficient mice, smaller EPSCs than in wild-type mice were detected in the second or third response to high-frequency stimulation (Bushell et al., 1996b; Pekhletski et al., 1996). This implies that synapses equipped with these mGluRs transmit high-frequency signals with higher efficiencies than do synapses without them. It is interesting to note that all cells decorated with synapses heavily labeled for group III mGluRs seem to be interneurons. This situation may allow effective feedback for high-frequency signals through interneuron subtypes that have selective targets (Buhl et al., 1994). Thus, the physiological significance of the differential synaptic regulation should be understood in light of identified neuronal connections in the complex circuitry.

\section{REFERENCES}

Aiba A, Chen C, Herrup K, Rosenmund C, Stevens CF, Tonegawa S (1994) Reduced hippocampal long-term potentiation and contextspecific deficit in associative learning in mGluR1 mutant mice. Cell 79:365-375.

Amaral DG, Witter MP (1995) Hippocampal formation. In: The rat nervous system, second edition (Paxinos G, ed), pp 443-493. San Diego: Academic.

Bakst I, Avendano C, Morrison JH, Amaral DG (1986) An experimental analysis of the origins of somatostatin-like immunoreactivity in the dentate gyrus of the rat. J Neurosci 6:1452-1462.

Baskys A, Gerlai R, Pekhletski R, Roder J, Hampson DR (1996) Physiological and behavioral studies of mice lacking type 4 mGluRs. Neuropharmacology 35:A2.

Baude A, Nusser Z, Roberts JDB, Mulvihill E, McIlhinney RAJ, Somogyi $\mathrm{P}$ (1993) The metabotropic glutamate receptor (mGluR1 $\alpha$ ) is concentrated at perisynaptic membrane of neuronal subpopulations as detected by immunogold reaction. Neuron 11:771-787.

Boulton CL, Irving AJ, Southam E, Potier B, Garthwaite J, Collingridge GL (1994) The nitric oxide-cyclic GMP pathway and synaptic depression in rat hippocampal slices. Eur J Neurosci 6:1528-1535.

Bradley SR, Levey AI, Hersch SM, Conn PJ (1996) Immunocytochemical localization of group III metabotropic glutamate receptors in the hippocampus with subtype-specific antibodies. J Neurosci 16:2044-2056.

Bramham CR, Torp R, Zhang N, Storm-Mathisen J, Ottersen OP (1990) Distribution of glutamate-like immunoreactivity in excitatory hippocampal pathways: a semiquantitative electron microscopic study in rats. Neuroscience 39:405-417.

Buckmaster PS, Wenzel HJ, Kunkel DD, Schwartzkroin PA (1996) Axon arbors and synaptic connections of hippocampal mossy cells in the rat in vivo. J Comp Neurol 366:270-292.

Buhl EH, Halasy K, Somogyi P (1994) Diverse sources of hippocampal unitary inhibitory postsynaptic potentials and the number of synaptic release sites. Nature 368:823-828.

Bushell TJ, Jane DE, Tse H-W, Watkins JC, Garthwaite J, Collingridge GL (1996a) Pharmacological antagonism of the actions of group II and III mGluR agonists in the lateral perforant path of rat hippocampal slices. Br J Pharmacol 117:1457-1462.

Bushell TJ, Sansig G, Shigemoto R, Flor P, Kuhn R, Knoepfel T, Schroeder M, Collett VL, Collingridge GL, van der Putten H (1996b) An impair- ment of hippocampal synaptic plasticity in mice lacking mGlu7 receptors. Neuropharmacology 35:A6.

Coyle JT, Schwarcz R (1976) Lesion of striatal neurones with kainic acid provides a model for Huntington's chorea. Nature 263:244-246.

Crépel V, Aniksztejn L, Ben-Ari Y, Hammond C (1994) Glutamate metabotropic receptors increase a $\mathrm{Ca}^{2+}$-activated nonspecific cationic current in CA1 hippocampal neurons. J Neurophysiol 72:1561-1569.

Davies CH, Clarke VRJ, Jane DE, Collingridge GL (1995) Pharmacology of postsynaptic metabotropic glutamate receptors in rat hippocampal CA1 pyramidal neurones. Br J Pharmacol 116:1859-1869.

Di Iorio P, Battaglia G, Ciccarelli R, Ballerini P, Giuliani P, Poli A, Nicoletti F, Caciagli F (1996) Interaction between A1 adenosine and class II metabotropic glutamate receptors in the regulation of purine and glutamate release from rat hippocampal slices. J Neurochem 67:302-309.

Flor PJ, van der Putten H, Rüegg D, Lukic S, Leonhardt T, Bence M, Sansig G, Knöpfel T, Kuhn R (1997) A novel splice variant of a metabotropic glutamate receptor, human mGluR7b. Neuropharmacology 36:153-159.

Fotuhi M, Standaert DG, Testa CM, Penney JB, Young AB (1994) Differential expression of metabotropic glutamate receptors in the hippocampus and entorhinal cortex of the rat. Mol Brain Res 21:283-292.

Frotscher M, Leranth C (1985) Cholinergic innervation of the rat hippocampus as revealed by choline acetyltransferase immunocytochemistry: a combined light and electron microscopic study. J Comp Neurol 239:237-246.

Gereau RW, Conn PJ (1995a) Multiple presynaptic metabotropic glutamate receptors modulate excitatory and inhibitory synaptic transmission in hippocampal area CA1. J Neurosci 15:6879-6889.

Gereau RW, Conn PJ (1995b) Roles of specific metabotropic glutamate receptor subtypes in regulation of hippocampal CA1 pyramidal cell excitability. J Neurophysiol 74:122-129.

Glitsch M, Llano I, Marty A (1996) Glutamate as a candidate retrograde messenger at interneurone-Purkinje cell synapses of rat cerebellum. J Physiol (Lond) 497:531-537.

Goldschmidt RB, Steward O (1980) Preferential neurotoxicity of colchicine for granule cells of the dentate gyrus of the adult rat. Proc Natl Acad Sci USA 77:3047-3051.

Guérineau NC, Gähwiler BH, Gerber U (1994) Reduction of resting K+ current by metabotropic glutamate and muscarinic receptors in rat CA3 cells: mediation by G-proteins. J Physiol (Lond) 474:27-33.

Guérineau NC, Bossu J-L, Gähwiler BH, Gerber U (1995) Activation of a nonselective cationic conductance by metabotropic glutamatergic and muscarinic agonists in CA3 pyramidal neurons of the rat hippocampus. J Neurosci 15:4395-4407.

Han Z-S, Buhl EH, Lörinczi Z, Somogyi P (1993) A high degree of spatial selectivity in the axonal and dendritic domains of physiologically identified local-circuit neurons in the dentate gyrus of the rat hippocampus. Eur J Neurosci 5:395-410.

Harvey J, Palmer MJ, Irving AJ, Clarke VRJ, Collingridge GL (1996) NMDA receptor dependence of mGlu-mediated depression of synaptic transmission in the CA1 region of the rat hippocampus. Br J Pharmacol 119:1239-1247.

Hayashi Y, Momiyama A, Takahashi T, Ohishi H, Ogawa-Meguro R, Shigemoto R, Mizuno N, Nakanishi S (1993) Role of a metabotropic glutamate receptor in synaptic modulation in the accessory olfactory bulb. Nature 366:687-690.

Ikeda SR, Lovinger DM, McCool BA, Lewis DL (1995) Heterologous expression of metabotropic glutamate receptors in adult rat sympathetic neurons: subtype-specific coupling to ion channels. Neuron 14:1029-1038.

Johansen PA, Chase LA, Sinor AD, Koerner JF, Johnson RL, Robinson MB (1995) Type 4a metabotropic glutamate receptor: identification of new potent agonists and differentiation from the L-(+)-2-amino-4phosphonobutanoic acid-sensitive receptor in the lateral perforant pathway in rats. Mol Pharmacol 48:140-149.

Kinoshita A, Ohishi H, Neki A, Nomura S, Shigemoto R, Takada M, Nakanishi S, Mizuno N (1996a) Presynaptic localization of a metabotropic glutamate receptor, mGluR8, in the rhinencephalic areas: a light and electron microscope study in the rat. Neurosci Lett 207:61-64.

Kinoshita A, Ohishi H, Nomura S, Shigemoto R, Nakanishi S, Mizuno N (1996b) Presynaptic localization of a metabotropic glutamate receptor, mGluR4a, in the cerebellar cortex: a light and electron microscope study in the rat. Neurosci Lett 207:199-202. 
Kishi K, Stanfield BB, Cowan WM (1980) A quantitative EM autoradiographic study of the commissural and associational connections of the dentate gyrus in the rat. Anat Embryol 160:173-186.

Koerner JF, Cotman CW (1981) Micromolar L-2-amino-4-phosphonobutyric acid selectively inhibits perforant path synapses from lateral entorhinal cortex. Brain Res 216:192-198.

Lanthorn TH, Ganong AH, Cotman CW (1984) 2-amino-4-phosphonobutyrate selectively blocks mossy fiber-CA3 responses in guinea pig but not rat hippocampus. Brain Res 290:174-178.

Laurie DJ, Boddeke HWGM, Hiltscher R, Sommer B (1996) HmGlu a novel splice variant of the human type I metabotropic glutamate receptor. Eur J Pharmacol 296:R1-R3.

Leranth C, Frotscher M (1987) Cholinergic innervation of hippocampal GAD- and somatostatin-immunoreactive commissural neurons. J Comp Neurol 261:33-47.

Leranth C, Malcolm AJ, Frotscher M (1990) Afferent and efferent synaptic connections of somatostatin-immunoreactive neurons in the rat fascia dentata. J Comp Neurol 295:111-122.

Lu Y-M, Jia Z, Janus C, Henderson JT, Gerlai R, Wojtowicz JM, Roder JC (1997) Mice lacking metabotropic glutamate receptor 5 show impaired learning and reduced CA1 long-term potentiation (LTP) but normal CA3 LTP. J Neurosci 17:5196-5205.

Luján R, Nusser Z, Roberts JDB, Shigemoto R, Somogyi P (1996) Perisynaptic location of metabotropic glutamate receptors mGluR1 and mGluR5 on dendrites and dendritic spines in the rat hippocampus. Eur J Neurosci 8:1488-1500.

Macek TA, Winder DG, Gereau RW, Ladd CO, Conn PJ (1996) Differential involvement of group II and group III mGluRs as autoreceptors at lateral and medial perforant path synapses. J Neurophysiol 76:3798-3806.

Maglóczky Z, Acsády L, Freund TF (1994) Principal cells are the postsynaptic targets of supramammillary afferents in the hippocampus of the rat. Hippocampus 4:322-334.

Manzoni O, Bockaert J (1995) Metabotropic glutamate receptors inhibiting excitatory synapses in the CA1 area of rat hippocampus. Eur J Neurosci 7:2518-2523.

Manzoni OJ, Manabe T, Nicoll RA (1994) Release of adenosine by activation of NMDA receptors in the hippocampus. Science 265:2098-2101.

Masu M, Tanabe Y, Tsuchida K, Shigemoto R, Nakanishi S (1991) Sequence and expression of a metabotropic glutamate receptor. Nature 349:760-765.

Matthews DA, Cotman C, Lynch G (1976) An electron microscopic study of lesion-induced synaptogenesis in the dentate gyrus of the adult rat. I. Magnitude and time course of degeneration. Brain Res 115:1-21.

McGinty JF, Henriksen SJ, Goldstein A, Terenius L, Bloom FE (1983) Dynorphin is contained within hippocampal mossy fibers: immunochemical alterations after kainic acid administration and colchicineinduced neurotoxicity. Proc Natl Acad Sci USA 80:589-593.

Milner TA, Bacon CE (1989) Ultrastructural localization of somatostatinlike immunoreactivity in the rat dentate gyrus. J Comp Neurol 290:544-560.

Minakami R, Katsuki F, Sugiyama H (1993) A variant of metabotropic glutamate receptor subtype 5: an evolutionally conserved insertion with no termination codon. Biochem Biophys Res Commun 194:622-627.

Nadler JV, Perry BW, Gentry C, Cotman CW (1980) Degeneration of hippocampal CA3 pyramidal cells induced by intraventricular kainic acid. J Comp Neurol 192:333-359.

Nadler JV, Perry BW, Gentry C, Cotman CW (1981) Fate of the hippocampal mossy fiber projection after destruction of its postsynaptic targets with intraventricular kainic acid. J Comp Neurol 196:549-569.

Nakajima Y, Iwakabe H, Akazawa C, Nawa H, Shigemoto R, Mizuno N, Nakanishi S (1993) Molecular characterization of a novel retinal metabotropic glutamate receptor mGluR6 with a high agonist selectivity for L-2-amino-4-phosphonobutyrate. J Biol Chem 268:11868-11873.

Nakanishi S, Masu M (1994) Molecular diversity and functions of glutamate receptors. Annu Rev Biophys Biomol Struct 23:319-348.

Neki A, Ohishi H, Kaneko T, Shigemoto R, Nakanishi S, Mizuno N (1996) Pre- and postsynaptic localization of a metabotropic glutamate receptor, mGluR2, in the rat brain: an immunohistochemical study with a monoclonal antibody. Neurosci Lett 202:197-200.

Nomura A, Shigemoto R, Nakamura Y, Okamoto N, Mizuno N, Nakanishi S (1994) Developmentally regulated postsynaptic localization of a metabotropic glutamate receptor in rat rod bipolar cells. Cell 77:361-369.

Nusser Z, Sieghart W, Benke D, Fritschy J-M, Somogyi P (1996) Differ- ential synaptic localization of two major $\gamma$-aminobutyric acid type A receptor $\alpha$ subunits on hippocampal pyramidal cells. Proc Natl Acad Sci USA 93:11939-11944.

Ohishi H, Shigemoto R, Nakanishi S, Mizuno N (1993a) Distribution of the messenger RNA for a metabotropic glutamate receptor, mGluR2, in the central nervous system of the rat. Neuroscience 53:1009-1018.

Ohishi H, Shigemoto R, Nakanishi S, Mizuno N (1993b) Distribution of the mRNA for a metabotropic glutamate receptor (mGluR3) in the rat brain: an in situ hybridization study. J Comp Neurol 335:252-266.

Ohishi H, Ogawa-Meguro R, Shigemoto R, Kaneko T, Nakanishi S, Mizuno N (1994) Immunohistochemical localization of metabotropic glutamate receptors, mGluR2 and mGluR3, in rat cerebellar cortex. Neuron 13:55-66.

Ohishi H, Akazawa C, Shigemoto R, Nakanishi S, Mizuno N (1995a) Distributions of the mRNAs for L-2-amino-4-phosphonobutyratesensitive metabotropic glutamate receptors, mGluR4 and mGluR7, in the rat brain. J Comp Neurol 360:555-570.

Ohishi H, Nomura S, Ding Y-Q, Shigemoto R, Wada E, Kinoshita A, Li J-L, Neki A, Nakanishi S, Mizuno N (1995b) Presynaptic localization of a metabotropic glutamate receptor, mGluR7, in the primary afferent neurons: an immunohistochemical study in the rat. Neurosci Lett 202:85-88.

Okamoto N, Hori S, Akazawa C, Hayashi Y, Shigemoto R, Mizuno N, Nakanishi S (1994) Molecular characterization of a new metabotropic glutamate receptor mGluR7 coupled to inhibitory cyclic AMP signal transduction. J Biol Chem 269:1231-1236.

Ouardouz M, Lacaille J-C (1995) Mechanisms of selective long-term potentiation of excitatory synapses in stratum oriens/alveus interneurons of rat hippocampal slices. J Neurophysiol 73:810-819.

Pekhletski R, Gerlai R, Overstreet LS, Huang XP, Agopyan N, Slater NT, Abramow-Newerly W, Roder JC, Hampson DR (1996) Impaired cerebellar synaptic plasticity and motor performance in mice lacking the mGluR4 subtype of metabotropic glutamate receptor. J Neurosci 16:6364-6373.

Petralia RS, Wang Y-X, Niedzielski AS, Wenthold RJ (1996) The metabotropic glutamate receptors, mGluR2 and mGluR3, show unique postsynaptic, presynaptic and glial localizations. Neuroscience 71:949-976.

Pin J-P, Duvoisin R (1995) Neurotransmitter receptors I. The metabotropic glutamate receptors: structure and functions. Neuropharmacology 34:1-26.

Pin J-P, Waeber C, Prézeau L, Bockaert J, Heinemann SF (1992) Alternative splicing generates metabotropic glutamate receptors inducing different patterns of calcium release in Xenopus oocytes. Proc Natl Acad Sci USA 89:10331-10335.

Ponce A, Bueno E, Kentros C, de Miera EV-S, Chow A, Hillman D, Chen S, Zhu L, Wu MB, Wu X, Rudy B, Thornhill WB (1996) G-proteingated inward rectifier $\mathrm{K}^{+}$channel proteins (GIRK1) are present in the soma and dendrites as well as in nerve terminals of specific neurons in the brain. J Neurosci 16:1990-2001.

Poncer J-C, Shinozaki H, Miles R (1995) Dual modulation of synaptic inhibition by distinct metabotropic glutamate receptors in the rat hippocampus. J Physiol (Lond) 485:121-134.

Romano C, Yang W-L, O'Malley KL (1996) Metabotropic glutamate receptor 5 is a disulfide-linked dimer. J Biol Chem 271:28612-28616.

Sahara Y, Westbrook GL (1993) Modulation of calcium currents by a metabotropic glutamate receptor involves fast and slow kinetic components in cultured hippocampal neurons. J Neurosci 13:3041-3050.

Sakurai T, Westenbroek RE, Rettig J, Hell J, Catterall WA (1996) Biochemical properties and subcellular distribution of the BI and rbA isoforms of $\alpha_{1 \mathrm{~A}}$ subunits of brain calcium channels. J Cell Biol 134:511-528.

Saugstad JA, Kinzie JM, Mulvihill ER, Segerson TP, Westbrook GL (1994) Cloning and expression of a new member of the L-2-amino-4phosphonobutyric acid-sensitive class of metabotropic glutamate receptors. Mol Pharmacol 45:367-372.

Saugstad JA, Segerson TP, Westbrook GL (1996) Metabotropic glutamate receptors activate G-protein-coupled inwardly rectifying potassium channels in Xenopus oocytes. J Neurosci 16:5979-5985.

Scanziani M, Gahwiler BH, Thompson SM (1995) Presynaptic inhibition of excitatory synaptic transmission by muscarinic and metabotropic glutamate receptor activation in the hippocampus: are $\mathrm{Ca}^{2+}$ channels involved? Neuropharmacology 34:1549-1557.

Scanziani M, Salin PA, Vogt KE, Malenka RC, Nicoll RA (1997) Use- 
dependent increases in glutamate concentration activate presynaptic metabotropic glutamate receptors. Nature 385:630-634.

Schoepp DD, Goldsworthy J, Johnson BG, Salhoff CR, Baker SR (1994) 3,5-Dihydroxyphenylglycine is a highly selective agonist for phosphoinositide-linked metabotropic glutamate receptors in the rat hippocampus. J Neurochem 63:769-772.

Sheng M, Liao YJ, Jan YN, Jan LY (1993) Presynaptic A-current based on heteromultimeric $\mathrm{K}^{+}$channels detected in vivo. Nature 365:72-75.

Shigemoto R, Nakanishi S, Mizuno N (1992) Distribution of the mRNA for a metabotropic glutamate receptor (mGluR1) in the central nervous system: an in situ hybridization study in adult and developing rat. J Comp Neurol 322:121-135.

Shigemoto R, Nomura S, Ohishi H, Sugihara H, Nakanishi S, Mizuno N (1993) Immunohistochemical localization of a metabotropic glutamate receptor, mGluR5, in the rat brain. Neurosci Lett 163:53-57.

Shigemoto R, Abe T, Nomura S, Nakanishi S, Hirano T (1994) Antibodies inactivating mGluR1 metabotropic glutamate receptor block long-term depression in cultured Purkinje cells. Neuron 12:1245-1255.

Shigemoto R, Wada E, Ohishi H, Takada M, Mizuno N, Roberts JDB, Somogyi P (1995) Differential presynaptic localization of metabotropic glutamate receptor subtypes, mGluR2/3 and mGluR7, in the rat hippocampus. Soc Neurosci Abstr 21:846.

Shigemoto R, Kulik A, Roberts JDB, Ohishi H, Nusser Z, Kaneko T, Somogyi P (1996) Target-cell-specific concentration of a metabotropic glutamate receptor in the presynaptic active zone. Nature 381:523-525.

Steward O (1976) Topographic organization of the projections from the entorhinal area to the hippocampal formation of the rat. J Comp Neurol 167:285-314.
Steward O, Scoville SA (1976) Cells of origin of entorhinal cortical afferents to the hippocampus and fascia dentata of the rat. J Comp Neurol 169:347-370.

Swanson LW, Wyss JM, Cowan WM (1978) An autoradiographic study of the organization of intrahippocampal association pathways in the rat. J Comp Neurol 181:681-716.

Swartz KJ, Bean BP (1992) Inhibition of calcium channels in rat CA3 pyramidal neurons by a metabotropic glutamate receptor. J Neurosci $12: 4358-4371$.

Takahashi T, Forsythe ID, Tsujimoto T, Barnes-Davies M, Onodera K (1996) Presynaptic calcium current modulation by a metabotropic glutamate receptor. Science 274:594-597.

Tanabe Y, Masu M, Ishii T, Shigemoto R, Nakanishi S (1992) A family of metabotropic glutamate receptors. Neuron 8:169-179.

Thomsen C, Pekhletski, Haldeman B, Gilbert TA, O'hara P, Hampson DR (1997) Cloning and characterization of a metabotropic glutamate receptor, mGluR4b. Neuropharmacology 36:21-30.

Wouterlood FG, Saldana E, Witter MP (1990) Projection from the nucleus reuniens thalami to the hippocampal region: light and electron microscopic tracing study in the rat with the anterograde tracer Phaseolus vulgaris-leucoagglutinin. J Comp Neurol 296:179-203.

Wyss JM (1981) An autoradiographic study of the efferent connections of the entorhinal cortex in the rat. J Comp Neurol 199:495-512.

Yokoi M, Kobayashi K, Manabe T, Takahashi T, Sakaguchi I, Katsuura G, Shigemoto R, Ohishi H, Nomura S, Nakamura K, Nakao K, Katsuki M, Nakanishi S (1996) Impairment of hippocampal mossy fiber LTD in mice lacking mGluR2. Science 273:645-647. 